\title{
A NYOMOZÁS STÁTUSZA ÉS FUNKCIÓJA A BÜNTETŐELJÁRÁSI RENDSZERBEN - TÖRTÉNETI ÉS RENDSZERTANI HÁTTÉR, SZABÁLYOZÁSI KONCEPCIÓK ÉS MEGOLDÁSOK
}

\author{
https://doi.org/10.51783/ajt.2021.3.04
}

\begin{abstract}
A modern jogrendszerekben a nyomozás fontos és általában szükségszerü szakasza a büntetöeljárásnak, ha azonban közelebbről szemügyre vesszük a szabályozási megoldásokat, nemcsak az angolszász és a kontinentális rendszerek közötti jelentős különbségekre figyelhetünk fel, de a magyar jog kapcsán is észrevehetjük a koncepcióváltásokat, vagy legalábbis az arra tett kísérleteket. Azt, hogy a nyomozás milyen helyet is foglal el a büntetōeljárásban (és egyáltalán ezt a helyét hogyan szerezte meg), három fö kérdés mentén kívánom vizsgálni. Ezek: 1. az eljárási szakaszok egymáshoz való viszonya; 2. a nyomozás alaposságának, „mélységének” kérdése; 3. a nyomozás feloszthatósága. Utóbbi kapcsán külön arra is próbálok választ találni, hogy a jogalkotót mi vezethette a hatályos Be.-ben bevezetett ún. osztott szerkezetü nyomozás megalkotásakor. A tanulmányban először a nyomozás történeti és rendszertani alapjait vizsgálom. A történelmi háttér vázlatos tisztázását követően azt is szemügyre veszem, hogy az angol és az amerikai büntetöeljárásokban mennyiben eltérő a nyomozás jogi szabályozása, illetve hogyan viszonyul ehhez a jogtudomány. Ezután kitérek arra, hogy a büntető eljárásjog társtudományának tekinthetö, és leginkább a nyomozással foglalkozó kriminalisztika ad e támpontokat az általam vizsgált három kérdés kapcsán, esetleg találhatunk-e itt a jogtudományba vagy a jogi szabályozásba is átszivárgó teóriákat. Végül a legrészletesebben a hazai jogi szabályozással és a kapcsolódó jogtudományi álláspontokkal foglalkozom: eddigi hat büntetőeljárási kódexünk nyomozásra vonatkozó rendelkezéseit és az ehhez kötődő elméleti álláspontokat ismertetem. Mindezek eredményeként remélhetöleg legalább részleges válaszokat tudok adni az általam feltett kérdésekre, és meg tudom világítani a jelenlegi szabályozás okait, valamint annak kialakulófélben lévő gyakorlatát.
\end{abstract}

• PhD, LL.M., vezetöhelyettes ügyész, Miskolci Járási Ügyészség, 3525 Miskolc, Dózsa György u. 5-7. E-mail: szekely.gyorgy@mku.hu. 


\section{BEVEZETŐ}

A hatályos Be. jelentősen átalakította a büntetőeljárás több jogintézményét. A változások a nyomozást is érintették: a törvény egyik újítása a nyomozási szakasz felderítésre és vizsgálatra bontása, és ennek mentén a nyomozó hatóság és az ügyészség jogköreinek és kapcsolatának újragondolása.

A törvényben azonban a nyomozás továbbra is önálló és hangsúlyos szakasza az eljárásnak, sőt, a Be. felszámolta a korábbi önálló vádemelési szakaszt, így az ügyészség a vádemeléssel kapcsolatos döntéseit is a nyomozás keretében hozza meg.

A jogszabályi változások dacára azonban továbbra sem megoldott dilemma, hogy a nyomozás a tárgyalással egyenértékű fázis-e, vagy szerepe inkább csak előkészítő. Az is régi vita, hogy a nyomozás során milyen „mélységü” felderítés, illetve bizonyítás indokolt.

A továbbiakban ez utóbbi probléma mentén három - egymással összefüggő - kérdésre keresek válaszokat: 1. Milyen szerepet szán az eljárásban a jogalkotó a nyomozásnak (milyen viszonyban áll egymással a nyomozási és a bírósági szakasz)?; 2. Hogyan szabályozzák a nyomozás „mélységét” (mennyire folyjék bizonyítás, a valóság kiderítésének milyen foka érendő el)?; és hogy 3. Vannak-e példák a nyomozás felosztására, osztályozására? Utóbbi kapcsán arra is keresem a választ, hogy a hatályos jogba újként bevezetett osztott szerkezetű nyomozásnál milyen indokok vezethették a jogalkotót.

\section{TÖRTÉNETI ÉS RENDSZERTANI HÁTTÉR}

\subsection{AZ INKVIZITÓRIUS RENDSZER MINT A NYOMOZÁS ALAPJA}

A jogtudományban a büntetőeljárás nyomozási szakaszát az inkvizitórius rendszer kialakulásával szokás összekötni. Farkas szerint „Az inkvizitórius rendszer lényege - mint neve is mutatja - a nyomozás, a tényállás valósághű felderítésére törekvés [...]". ${ }^{1}$ A szerzők továbbá az ún. vegyes rendszer kapcsán is megállapítják, hogy nyomozási szakaszát az inkvizitórius, míg a tárgyalásit az akkuzatórius modellből merítette (ld. később).

Bár a szerzők többsége az inkvizitórius rendszer alapjait az egyházi inkvizícióval köti össze, ${ }^{2}$ azonban a bírósági tárgyalás megalapozásának előzményei már ennél korábban is felbukkannak. Az ókori görög és római eljárások ugyan csak perszakaszt tartalmaztak, azonban a perelőkészítés intézménye ismert volt, bár ez még nem a vád bizonyítékainak megalapozását jelentette. A római jogban azonban egyes jelentős perekben a vád képviselőjének lehetősége volt a vádat alaposabban előkészíteni,

1 FARKAS Ákos: „A büntetőeljárási rendszerek történeti fejlődésének sajátosságai” in BRAGYovA András (szerk.): Tanulmányok a bünügyi tudományok köréből (Miskolc: Gazdász Elasztik 2013) 52.

2 Pl. Farkas (1. lj.) 52. vagy Mireille Delmas-Marty - J. R. Spencer (szerk.): European Criminal Procedures (Cambridge: Cambridge University 2006) 7. 
és ennek érdekében előzetes adatgyüjtést folytathattak. Többen a nyomozás ókori kriminalisztikai előzményeit (pl. halottszemle) is hangsúlyozzák. ${ }^{3}$

Később - ahogy Stipta rámutat -, a középkori germán-frank jogokban már megjelent annak az igénye, hogy jelentős ügyekben ne a sértett döntsön a vádemelésről, hanem királyi tisztviselők a sértett akaratától függetlenül, hivatalból vizsgálják a súlyos bűncselekmények körülményeit, elsősorban kihallgatások útján. ${ }^{4}$ A hivatalbóliság kapcsán Erdei meg is jegyzi, hogy épp ez az elv adta hozzá a vádelvű őspertípushoz a mára nyomozásként ismert szakaszt. ${ }^{5}$

Langbein pedig kimutatja, hogy még a tisztán akkuzatórius hagyományú Angliában is kifejlődött egyfajta előkészítő eljárás: egy 1555-ben hozott jogszabály az ún. békebírák kezébe adta a per előkészítésének feladatát, akik jogosultak voltak idézések, elfogató parancsok kibocsátására, letartóztatások elrendelésére, továbbá a vádló sértett segítése érdekében meghallgatták terheltet és a vádló tanúit, illetve segítettek megfogalmazni a vádiratot. ${ }^{6}$

Az inkvizitórius (vagy nyomozóelvű) rendszer volt viszont az, ahol a nyomozás szabályai ténylegesen kikristályosodtak. A legtöbben úgy látják, hogy e rendszer elterjedését az észak-itáliai egyetemek elméleti munkássága és az 1215-ös IV. Lateráni Zsinat rendelkezései segítették elő. ${ }^{7}$ Farkas kifejti, hogy III. Ince pápa tevékenysége folytán e forma az egyházi bíráskodásból terjedt át a világi bűncselekményekkel kapcsolatos eljárásokra. ${ }^{8}$ A XVI. századtól kezdve pedig sok országban már az inkvizitórius rendszerre épülő kódexeket alkottak (pl. 1532-ben a Constitutio Criminalis Carolina vagy 1670-ben az Ordonnance Criminelle), amelyekben hangsúlyos és részletesen szabályozott volt a nyomozás. ${ }^{9}$

Spencer szerint a középkorban az egész európai kontinenst az inkvizitórius rend jellemezte; ekkor alakult ki például a kihallgatás intézménye, és a vallomások rögzítése is. Angliában viszont ugyanekkor még mindig az istenítéleteken alapuló vádelvű eljárás működött. Így kijelenti, hogy - negatívumai ellenére - a kontinentális inkvizitórius eljárásokat a racionalitás és a civilizáltság jellemezte, míg az angol eljárás durva és kezdetleges volt. Spencer szerint e racionális rendszert később a tortúra „rontotta meg”. Majd Napóleon 1808. évi Code d’instruction criminelle-je a

3 Pl. Cicero a Verres elleni perben több hónapot kapott bizonyítékgyűjtésre. Ld. Marcus Tullius CicERo: Válogatott vádbeszédek [Fordította, jegyzetekkel ellátta, és a bevezetést írta: NóTÁRI Tamás] (Szeged: Lectum 2010); BALláNÉ FüszTER Erzsébet: Krimináltechnika (Budapest: Dialóg-Campus 2019) 20.; Balláné Füszter Erzsébet - Kunos Imre - LaKatos János: Bevezetés a kriminalisztikába (Budapest: Rejtjel 2004) 9-10.

4 HoRvÁth Pál (szerk.): Egyetemes jogtörténet I. (Budapest: Nemzeti Tankönyvkiadó 1997) 80.

5 ERDEI Árpád: Tanok és tévtanok a büntető eljárásjog tudományában (Budapest: ELTE Eötvös 2011) 75.

6 John H. Langbein: The Origins of Adversary Criminal Trial (New York: Oxford University 2003) 40-47.

7 Pl. Horváth (szerk.) (4. lj.) 80.; BAlogh Jenő - Edvi IllÉs Károly - VARGHa Ferencz: A bünvádi perrendtartás magyarázata. Első kötet (Budapest: Grill 1898) 143-144.; Angyal Pál: A magyar büntető eljárásjog tankönyve (Budapest: Atheneum 1916) 17.

8 FARKas Ákos - Róth Erika: A büntetőeljárás (Budapest: Wolters Kluwer 2018) 53.

9 Angyal (7. lj.) 19-20.; FARKAS-Róth (8. lj.) 55-56.; FARKAS (1. lj.) 52-57.; Balogh-Edvi IllÉSVARGHA I. (7. lj.) 147. 
korábbi („megrontatlan”) inkvizitórius eljárás módszereit egy tárgyalást előkészítő stádiumként használta fel. ${ }^{10}$

Az inkvizitórius eljárásokat felváltó vegyes rendszert a jogtudomány egyértelmủen a napóleoni kódexhez köti. Mind a magyar, mind a külföldi felfogás szerint a vegyes jelző épp azt jelenti, hogy a kétszakaszú eljárásból az első, előkészítő (nyomozási) szakasz az inkvizitórius, míg a vád alapján meginduló bírósági szakasz az akkuzatórius modellből ered. ${ }^{11}$ Balogh azonban felhívja a figyelmet arra, hogy a napóleoni jogalkotás az erőteljesen inkvizitórius (annak minden negatívumát magán viselő) 1670. évi Ordonnance-t kívánta leváltani, azonban az 1808. évi kódexet megelőző két korábbi reformjogszabály még jobban merített az akkori angol jog - Balogh szerint haladóbb - eszközeiből. Így végül a napóleoni kódexben a perszakaszban lehet csak üdvözölni a terheltre kedvezőbb szabályokat, míg az előkészítő szakaszt a korábbi (inkvizitórius) hagyományok alapján szabályozta. ${ }^{12}$

\subsection{A NYOMOZÁSI SZAKASZ MAGYAR FEJLŐDÉSE}

A magyar jogban is kimutathatók az inkvizitórius hatások. Angyal és Degré is rámutat, hogy a késői és a hanyatló feudalizmus eljárása már a nyomozóelvet követte, bár a nemesek és nem nemesek perének sajátos kettőssége fennmaradt. A nem nemesek elleni ún. sommás eljárás megindulhatott ugyan vád vagy feljelentés alapján is, annak rendes módja azonban a „bűntettesek hivatalos kinyomozása” volt. ${ }^{13}$ Vargha is megállapítja, hogy „az előkészítő eljárás régi időktől fogva önálló tagozata a pernek”, és már a XVI. századtól ismert a vizsgálati szakasz, amelynek típusai az általános vizsgálat (inquisitio generalis - bűncselekmény forog-e fenn), a különös vizsgálat (inquisitio specialis - a meghatározott személy elleni vizsgálat) és az ún. inquisitio generalissima (amelyet a vármegyék tisztviselői általánosságban, közbiztonsági intézkedésként végeztek) voltak. Ezek azonban még nem feleltethetők meg a későbbi felosztásnak (nyomozás, vizsgálat), mert előbbiek egy személy kezében összpontosultak. Vargha arra is felhívja a figyelmet, hogy a vizsgálat korábban - a vádelv hiánya miatt - nem a vádló tájékoztatására szolgált, hanem az ítélet alapjait képezte. ${ }^{14}$ A XIX. század elejére jellemző eljárást pedig Vuchetich „vegyes inkvizitóriusnak” nevezi, aholis az eljárás „inkvizícióval (vizsgálattal) kezdődik, ami a bíró hivatalos kötelezettségéhez tartozik [...]”. ${ }^{15}$

10 Delmas-Marty-Spencer (2. lj.) 7-11.

11 Pl. CsÉKA Ervin (szerk.): A büntetőeljárási jog alapvonalai I. (Szeged: Bába 2006) 28-29., FARKASRóTH (9. lj.) 44-58.; ERDEI Árpád: „Az inkvizíciós és a kontradiktórius vonások a büntető eljárási jogrendszerekben” Jogtudományi Közlöny 1998/4. 127-129.; Delmas-MarTy-Spencer (2. lj.) 10-13.

12 Balogh-Edvi Illés-Vargha I. (7. lj.) 162-167.

13 Angyal (7. lj.) 28-29.; BónIs György - Degré Alajos - VARGa Endre: A magyar bírósági szervezet és perjog története (Budapest: Művelődésügyi Minisztérium Levéltári Osztálya 1961) 124.

14 Balogh Jenő - Edvi IllÉs Károly - VARgha Ferencz: A bünvádi perrendtartás magyarázata. Második kötet. (Budapest: Grill 1897) 1-2.

15 Vucheтісн Mátyás: A magyar büntetőjog rendszere. II. könyv: Gyakorlati büntetőjog (Buda: Magyar Királyi Egyetem Nyomdája 1819) 62. 
A magyar vegyes rendszer kapcsán első kódexünk miniszteri indokolása a történeti előzményeket tudományos igénnyel részletezve világossá teszi a korábbi nyomozó rendszer hatásait, majd ismerteti a napóleoni kodifikációt és annak következményeit. Végül leszögezi, hogy a korszak rendszerei ún. vegyes rendszerek, amely „A nyomozó rendszer javarészét felhasználja az előkészitő eljárásban, hol arra a bizonyitékok megállapitása végett legfőbb szükség van. [...] Egyebekben a hivatalból való eljárás és az anyagi igazságra törekvés elfogadásával módosított vádelvnek enged túlsúlyt." ${ }^{16}$

E ponton szükséges kitérni a korábbi jogtudományban gyakrabban emlegetett ún. anyagi igazság elvére, amely összefügg az általam vizsgált második, a nyomozás „mélységére” irányuló kérdéssel. Korábban ezt még alapelvként tárgyalták, mára e szerepét elvesztette, annak ellenére, hogy a törvényszövegekben megfogalmazása megjelent, és az indokolások, kommentárok is hivatkoztak rá. Az elvet röviden akként definiálhatjuk, mint az arra való törekvést, hogy a - jogilag releváns - történeti tényállást teljesen, annak valójában felderítsék, és egyben bizonyítsák is. Az anyagi igazság elvét az alaki vagy perbeli igazság elvével szokás párba állítani. Utóbbinál a bíróság maga nem törekszik - hivatalból - bizonyításra, a tényleges valóság feltárására, hanem a felek előtte lefolytatott bizonyítása alapján dönt. Az ellenpárt a kontinentális és az angolszász bizonyítás relációjában szokták felállítani. Finkey viszont rámutat, hogy az anyagi igazság fogalma közel sem olyan egyértelmủ, és számos téves nézet övezi. Úgy látja, hogy „[A]z anyagi és alaki igazság kifejezés a büntető és a polgári perjog képzelt vagy erőszakolt antagonizmusából ered”. Szerinte azonban csak egyféle igazság létezhet, és a büntetőpernek is csak ez lehet célja. ${ }^{17}$

Mindezekből az látszik, hogy az anyagi igazság, már ellenpárja okán sem lenne alkalmazható a nyomozási szakaszra. Az alaki igazság keresésének lehetősége ugyanis - kontradiktórius bizonyítás hiányában - a nyomozásra értelmezhetetlen. Mégis azt kell majd látnunk, hogy az anyagi (vagy objektív) igazság elérésének követelményét a jogtudomány és a joggyakorlat kiterjesztette a nyomozásra is, azaz e szakasznak is feladata lehet a tényállás teljes körű feltárása és bizonyítása. Ez esetben azonban az ellenpár nem a perbeli/alaki igazsáskeresés, hanem inkább az angolszász jogokból ismert adatgyüjtéssel, a bizonyítékok feltérképezésével megelégedő nyomozás.

\subsection{A NYOMOZÁS SZEREPE AZ ANGOLSZÁSZ RENDSZEREKBEN}

Amellett, hogy az angolszász ${ }^{18}$ eljárások rendszerüket tekintve térnek el a kontinentálistól, többen hangsúlyozzák az eljárási szakaszok viszonyának különbözőségét is. $\mathrm{Az}$ angol-amerikai szakirodalom a nyomozás szót is kétféle értelemben használja.

${ }^{16}$ 1896. évi XXXIII. törvénycikk indokolása a bünvádi perrendtartásról.

${ }^{17}$ FINKEy Ferenc: Anyagi igazság és téves jelszavak a büntető eljárásban (Budapest: A Magyar Jogi Szemle kiadása 1927) 15.

${ }^{18}$ E kifejezés alatt az Egyesült Királyság és az Amerikai Egyesült Államok rendszereit fogom vizsgálni. 
Investigation alatt értik a tárgyalást megelőző fázist, de jelenti a valóság feltárásásra irányuló megismerő tevékenységet is. Utóbbi az alapja annak a megközelítésnek, miszerint a kontinentális bíró, mert aktív, és hivatalból vesz részt a bizonyításban, maga is „nyomoz” az igazság érdekében. (Ezért vélik sokan ma is inkvizitóriusnak a kontinentális büntetőeljárásokat.)

Az angolszász nyomozások ismert jellemzője a már említett egyszerű, gyors, adatgyűjtésszerű, a bizonyítékok beazonosítására szorítkozó forma. Az is tudott, hogy a nyomozás során keletkezett akta nem befolyásolhatja a bíróságot, amely döntését csak a tárgyaláson előtte lefolytatott bizonyításra alapozza. ${ }^{19}$ További, az angolszász megközelítésre jellemző kérdés, hogy a tárgyalás azonos-e magával a büntetőeljárással, amely egyben azt veti fel, hogy a nyomozás része-e a büntetőeljárásnak. ${ }^{20} \mathrm{Ez}$ utóbbi - ahogy látni fogjuk - több szerzőnél és a jogi szabályozásban is felvetődik.

Reichel az angolszász és a kontinentális rendszerek nemzetközi összehasonlító vizsgálata során ügyféli (common law országok) és inkvizitórius rendszereket (kontinentális és szocialista országok) különböztet meg négy kérdés mentén, amelyből most a második a lényeges: Hogyan derítsük ki az igazságot? Erre ugyanis azt válaszolja, hogy az ügyféli rendszerben az igazság az ellenérdekű felek versengése révén derül ki, így a hangsúly a tárgyaláson van, míg az inkvizitórius szisztémában az igazság egy vizsgálat lefolytatásával tárul fel, így itt a hangsúly a nyomozáson van. ${ }^{21}$

Spencer szintén jogösszehasonlítás keretében az inkvizitórius-akkuzatórius felosztás fenntarthatóságát vizsgálja a mai kontinentális és angol rendszerekre vonatkozóan. Megállapítja, hogy mindkét rendszerben létezik és fontos a nyomozási szakasz, ám míg az itt készült dokumentumok a kontinentális rendszerben a bírói döntés alapjául szolgálhatnak, addig ez az angol jogban csak a vádalkus ügyekben jellemző. Az ártatlanság vélelmével összefüggésben jegyzi meg, hogy a kontinentális jogrendekben a nyomozás gyakran olyan alapos és elhúzódó, hogy ez a bűnösség vélelmét érezteti. A terhelt szerepe kapcsán pedig azt állapítja meg, hogy az mára már hasonlóan alakul a nyomozás során mind Angliában, mind a kontinensen, mert a gyanúsítottat a nyomozó hatóság is kihallgathatja (1984 előtt ez nem így volt). Végül a bírói bizonyítás kapcsán veti fel ő is, hogy a kontinentális bíró maga is „nyomoz” az igazság érdekében, de ennek nyomai mára már az angol bíráknál is megjelennek (szintén a vádalkut hozva példaként). ${ }^{22}$

$\mathrm{Az}$ amerikai Dressler úgy fogalmaz, hogy a büntetőeljárás két részre osztható: nyomozási és bírósági szakaszra. A nyomozás „főszereplője” a rendőrnyomozó, aki saját észlelése vagy valamely információ alapján dönt a nyomozás megkezdéséről. Fontos megállapítása, hogy mivel a nyomozásnak nincs formalizált menete, ezért az alkotmányjogi szabályok - különösen az USA Alkotmányának Negyedik

${ }^{19}$ Farkas és Róth szavaival a nyomozás anyaga csak orientáló, tájékoztató jellegủ a vádló számára a vádemeléshez. FARKAS Ákos - RóTH Erika: Elöadások a büntetőeljárási jog köréből (Miskolc: Bíbor 2000) 96-97., 119.

${ }^{20}$ A magyar jogtudósok közül ezt Erdei is felveti. Ld. ERDEI (5. lj.) 81.

${ }^{21}$ Philip L. ReIchel: Comparative Criminal Justice Systems (New Jersey: Pearson Prentice Hall 2008) $165-166$.

${ }^{22}$ Delmas-Marty-Spencer (2. lj.) 20-27. 
Kiegészítése - határozzák meg a gyakorlatát. ${ }^{23}$ Dressler azonban azt állítja, hogy az USA büntetőeljárása ténylegesen nem tisztán akkuzatórius, a Legfelsőbb Bíróság ugyanis például a McNeil v. Wisconsin (1991) ügyben kimondta, hogy az igazságszolgáltatás mindig is inkvizitórius volt a nyomozási szakaszt illetően. ${ }^{24}$

Az USA büntetőeljárását vizsgáló munkájukban LaFave és szerzőtársai az eljárást tizenhét „lépésre” osztják, amelyek között helyet kapnak nyomozási részek is. A vádemelést megelőző tíz lépés között találhatunk olyan elemeket, mint például letartóztatást megelőző és követő nyomozás, gyanúsítás, ám az angolszász értelmezésnek megfelelően ezek között több bírói, vagy esküdtszéki hatáskör is van, illetve itt részletezik a letartóztatási szabályokat is. A nyomozás részletesebb ismertetése során a szerzők nem egy lineáris, illetve formális szabályrendszert vázolnak, hanem az alkotmányos, a terhelti jogok és garanciák mentén való megközelítés dominál. Bár írásuk átfogó, nem a tagállami szabályokat részletezi, azonban tipikus példaként említenek a nyomozás felosztására, osztályozására emlékeztető jogintézményeket is (pl. letartóztatással vagy anélkül folyó nyomozás, tettenéréses eljárás, illetve az egyes bűncselekménytípusoknál vagy eljárási körülményeknél alkalmazható ügyészségi vagy vádesküdtszéki nyomozás). Fontos azon megállapításuk is, amely szerint az amerikai eljárás igazságkeresésének két eleme van: 1. a bűncselekmény felderítése, 2 . annak meghatározása, hogy azt ki követte el. Ez pedig elsőként a nyomozás során realizálódik, amelynek célja általánosságban, hogy felderítsék a bűncselekményt, és azonosítsák az elkövetőt. A nyomozásban tehát arra törekszik a rendőrség és az ügyész, hogy a lehetséges információ- és bizonyítékforrásokat azonosítsák. Ezért a rendőrségnek lehetősége van meghatározott határok között a lehetséges tanúkat és gyanúsítottakat kikérdezni, személyeket és vagyontárgyakat átkutatni, megkövetelni a gyanúsított részvételét azonosítási eljárásokban, illetve informátorokat, fedett ügynököket alkalmazni. ${ }^{25}$

A nyomozás most vázolt jellege tetten érhető az USA jogalkotásában is. Jellemző, hogy a büntetőeljárási szabályokat egységesen, külön kódexek tartalmazzák, azonban valamennyi állam rendelkezik saját törvénnyel. Az egyes kódexekben a szabályozási megoldás változatos képet mutat, ám ritkán találhatunk kifejezetten a nyomozásra vonatkozó rendelkezéseket, inkább a nyomozásra vonatkoztatható terhelti alkotmányos kikötések a tipikusak (pl. házkutatási, lefoglalási, letartóztatási rendelkezések). A kódexek nagyrésze eleve a bírósági eljárással, vagy a vádemeléssel kezdődik, és a szabályok döntő hányada is a bírósági szakasszal foglalkozik. ${ }^{26}$

${ }^{23}$ Joshua Dressler: Understanding Criminal Procedure (New York: Matthew Bender 1997) 4-5. Az alkotmányos előírások nyomozásban való megjelenítését vizsgálja és hangsúlyozza a magyar jog kapcsán Finszter is. FinszTer Géza: „Az alkotmányos büntetőeljárás és a nyomozás” Fundamentum 1997/2. 109-115.

${ }^{24}$ Dressler (23. lj.) 29-30. Szintén a Legfelsőbb Bíróságnak a nyomozás során beszerzett bizonyítékok felhasználhatóságáról szóló döntései alapján mondja azt Erdei, hogy mára az USA-ban is elfogadott, hogy a nyomozás része a büntetőeljárásnak. ERDEI (5. lj.) 80-82.

${ }^{25}$ Wayne R. LAFAVE - Jerold H. IsRaEL - Nancy J. KIng: Criminal Procedure (Thomson West 2004) 6-23., 26-27.

${ }^{26} \mathrm{Pl}$. Texas büntetőeljárási törvényének 1.03. cikkelye elöírja a kódex céljai között (4. pont), hogy a nyomozás során is fel kell deríteni minden olyan körülményt, amely a bíróság előtt akár elítélésre, 
Az Egyesült Királyság jogrendjében viszont nincs a büntetőeljárás valamennyi szakaszát átfogóan szabályozó kódex. A büntetőeljárás szabályai több törvényből olvashatók ki, egyes eljárási szakaszokra külön jogszabályok vonatkoznak, külön törvényeket alkothatnak bủncselekmény típusokra, elkövetőkre, valamint eltérő jogszabályok vonatkozhatnak Skóciára és Észak-Írországra, sőt korábbi törvények bizonyos részei továbbra is hatályban maradnak. A nyomozással kapcsolatos írott jog itt valamivel részletesebb, és külön, ilyen tárgyú törvényekben jelenik meg. Az 1996. évi, nevében is a nyomozásra utaló Criminal Procedure and Investigation Act a II. részében például igen röviden meghatározza a nyomozás fogalmát és célját (olyan bűnügyi nyomozás, amelyet rendőrnyomozó vezet annak felderítése érdekében, hogy egy adott személy bűncselekménnyel gyanúsítható-e, és hogy e gyanúsított személy bünös-e - 22. szakasz), mindezzel egyidejüleg azonban a nyomozás gyakorlati részletszabályait alsóbbrendű jogalkotásra bízza. ${ }^{27}$ Szintén részben a nyomozásra vonatkozik a korábbi, 1984. évi Police and Criminal Evidence Act. Ez szerkezetét és tartalmát tekintve jobban hasonlít a kontinentális szabályozáshoz, azonban témakörei inkább az amerikai megoldást követik: terhelti alapjogokat érintő eljárási intézmények - különösen: házkutatás, lefoglalás, előállítás és letartóztatás - deklarálásáról szól leginkább, egy további fejezet viszont a rendőrségi kihallgatásról (annak rögzítési módjairól), illetve az előállított személyektől való bizonyítékszerzésről (DNS, motozás) rendelkezik. ${ }^{28}$

Spencer egyébként az angol nyomozásról azt írja, hogy a XIX. századig kezdetleges volt (az ügyek nagy része magánvádas volt, így a nyomozás is magánúton történt), és ezen csak a hivatásos rendőrség felállításával (1856) lépett túl. Az eljárást szerinte egyetlen jogszabály sem osztja szakaszokra, de az angol jogra is elfogadhatónak tartja a hármas felosztás (előkészítő, vádemelési és bírósági szakasz) alkalmazhatóságát. A nyomozás kapcsán ő is elsősorban a terhelti garanciákat hangsúlyozza, de egyrészt a nyomozást több ízben információgyűjtésnek aposztrofálja, másrészt az angol nyomozás legfőbb - a kontinentálistól eltérő - jellegzetességeként az angol rendőrség - ügyészségtől független - jelentős önállóságát emeli ki. Ez az adatok összegyüjtésén kívül a vádemelés kérdésére is kiterjed, ugyanis erről (azaz, hogy átadja-e az ügyet az ügyészségnek) a rendőrség önállóan dönt, még ha a Crown Prosecution Service 1984. évi felállításától maga a vádemelő és vádképviselő szerv már az ügyészség. ${ }^{29}$

akár felmentésre vezet, míg az 1.06. cikkely a házkutatás és lefoglalás garanciális szabályait erősíti meg: statutes.capitol.texas.gov/Docs/CR/htm/CR.1.htm. Szintén a kutatás/lefoglalás, és a letartóztatás kapcsán szerepelnek nyomozásra vonatkozó szabályok Alabama törvényében: law.justia. com/codes/alabama/2019/title-15/. Ennél több nyomozási elöírást találunk Montana kódexében. Itt már van külön, nyomozásra vonatkozó fejezet, de az „Investigative procedure” című 4. fejezet első része a halálesetek nyomozásával, föként a halottkémi eljárással foglalkozik, illetve rövidke elöírás rögzíti pl. az önvádra kötelezés tilalmát: leg.mt.gov/bills/mca/title_0460/chapter_0040/ parts_index.html. Hasonlóan, Louisiana kódexének nyomozásra vonatkozó szabályai is a halottkémi eljárás szabályaiban merülnek ki: law.justia.com/codes/louisiana/2019/code-of-criminalprocedure/article-101/.

${ }^{27}$ Lásd: www.legislation.gov.uk/ukpga/1996/25/contents.

${ }^{28}$ Lásd: www.legislation.gov.uk/ukpga/1984/60/contents.

${ }^{29}$ Delmas-Marty-Spencer (2. lj.) 13-16., 165-168. 


\section{A NYOMOZÁS KRIMINALISZTIKAI MEGKÖZELÍTÉSE}

A korábban a büntetőeljárás segédtudományának tekintett kriminalisztika mára többek szerint önálló tudománnyá vált. ${ }^{30}$ Fenyvesi azonban megjegyzi, hogy a kriminalisztika és a büntető eljárásjog (a tény és a jog fogalmai mentén elválaszthatóan) „szimbiotikus együttélésben van” ${ }^{31} \mathrm{Az}$ is vitathatatlan, hogy a kriminalisztika elsősorban az eljárás nyomozási szakaszával áll kapcsolatban, hiszen „a bűncselekmények nyomozásának, felderítésének tudománya”32 vagy „bűnügyi nyomozástan”33 néven említik igen korántól. ${ }^{34}$ Tremmel pedig a büntető eljárásjog és a kriminalisztika viszonyát úgy határozza meg, hogy „A Be. kötelező rendelkezései tehát megadják általában a nyomozási cselekmények törvényességi kereteit. A krimináltechnikai és krimináltaktikai követelmények, ajánlások csak e törvényességi kereteket töltik, és tölthetik ki [...]”. ${ }^{35}$ Emellett a kriminalisztika nem csak nyomozásra vonatkozó szabályok kereteinek tartalommal való kitöltését jelenti, hanem képes visszahatni a jogalkotásra is. ${ }^{36}$

Az összefüggés a kriminalisztika és a nyomozás között tehát egyértelmű. Az általam vizsgált három kérdés közül a kriminalisztika az eljárási szakaszok viszonyát illetően kevésbé, míg a nyomozás alaposságát, illetve feloszthatóságát illetően már jóval nagyobb eséllyel képes támpontokat nyújtani.

Az egyik legátfogóbb kriminalisztikai szakkönyvben, míg előbb Bócz a nyomozás elsősorban büntető eljárásjogi és más egyéb lehetséges fogalmait vizsgálja, ${ }^{37}$ addig Lakatos ezt követően a nyomozás kriminalisztikai fogalmát tisztázza. Rámutat, hogy a nyomozás e szempontból tágabb fogalom, mint a büntetőeljárási nyomozás, és alapvetően munka- és megismerési folyamatnak/tevékenységnek tekinti. Hozzáteszi azonban, hogy e folyamat mindig jogilag szabályozott, továbbá fontos jellemzője, hogy a „jogi szempontból releváns (vagy annak látszó) múltbeli, egyedi esemény valóságnak megfelelő feltárását és kívánt mértékủ megismerését (az ún. „anyagi igazság” megállapítását) és az eljárás sikeres lefolytatását” szolgája. ${ }^{38}$ Tulajdonképpen egyedi Lakatosnál (a további szerzők ennek kapcsán mindig őrá hivatkoznak) az a rendszerezés, amely a nyomozás fogalmának tisztázását követő-

30 BallánÉ (3. lj.) 13. vagy Angyal Miklós (szerk.): Kognitív kriminalisztika (Budapest: DialógCampus 2019) 13.

31 Fenyvesi Csaba: „A magyar büntető eljárásjog tudomány aktuális piramis modellje - monográfiák alapján” Miskolci Jogi Szemle 2019/2. 271.

32 Garamvölgyi Vilmos (főszerk.): Kriminalisztika Általános Rész (Budapest: Belügyminisztérium Tanulmányi és Módszertani Osztálya 1961) 8.

${ }^{33}$ Bíró Gyula: Kriminalisztika (Debrecen: DE Kossuth Egyetemi 2004) 12.

${ }^{34} \mathrm{Az}$ összefüggésre már igen korán rámutattak a magyar jogtudományban is. Kármán a XX. század eleji írásában új tudománynak nevezi a kriminalisztikát, amely eredetileg a bủnvádi eljárásjog segédtudománya volt. KÁRMÁN Elemér: „A nyomozás tudománya” Jogtudományi Közlöny 1909/18. 157159.

35 Tremmel Flórián - Fenyvesi Csaba: Kriminalisztika tankönyv és atlasz (Budapest-Pécs: DialógCampus 2002) 22. (a későbbi kiadásokban ugyanígy).

${ }^{36} \mathrm{Pl}$. a bizonyítási kísérlet „nyomozási kísérlet” néven csak a büntetőeljárásról szóló 1962. évi 8. tvr.ben jelent meg (143. §), ám még a nyomozás szabályai között.

37 Bócz Endre (szerk.): Kriminalisztika 1. (Budapest: BM 2004) 89-120.

${ }^{38}$ Bócz (szerk.) (36. lj.) 121-122. 
en önállóan definiálja a felderítést és a bizonyítást, mint a nyomozáson belüli további fogalmakat. A nyomozást ekként megismerési folyamatnak tekinti, míg a felderítést és a bizonyítást a nyomozáson belül a megismerés fokozatainak. Ebben az értelemben pedig a felderítés adatgyűjtő tevékenység, míg a bizonyítás a releváns adatok valódiságát igazoló eljárás (jogi keretek között). Lényeges megjegyzése Lakatosnak, hogy a büntető eljárásjogi ismeretanyag, illetőleg a jogi szabályozás a felderítéssel csak érintőlegesen foglalkozik, nem határozza meg a fogalmát. Utal továbbá arra is, hogy a felderítés kevésbé szabályozott terület, mint a bizonyítás, így például semmi nem írja elő, hogy a felderítés folyamán beszerzett minden adatot rögzíteni kellene. ${ }^{39}$

A felderítés fogalmát a kriminalisztikában van, aki még szűkebben húzza meg. Így azt Dobos az ismeretlen tettes személyének megállapítására irányuló tevékenységgel azonosítja, míg a vizsgálati szakaszt a felderítéshez képest egy „más, idegen területnek" mondja. ${ }^{40}$ Kovács pedig Dobos írásának magyarázata során utal arra, hogy felderítés és a vizsgálat kriminalisztikában alkalmazott fogalmai, illetve a rendőrségen belüli szervezeti- vagy munkamegosztások ilyen megjelölései nem azonosak a hatályos Be. felderítési és vizsgálati fogalmaival. Sőt úgy fogalmaz, hogy gyakori a „terminológiai zavar”, és a vizsgálati szakasz (nem Be. szerinti) megkezdődését „egyfajta sajátos titok lebegi körül”; arra vonatkozóan pedig, hogy a nyomozó szerven belül mikor kerüljön át (ha egyáltalán átkerül) az ügy a felderítést végző nyomozótól a vizsgálóhoz, azt mondja, hogy „ahány ház, annyi szokás”. Ő maga egyébként egy saját felosztást vezet be: a felderítésszerű „ügytől a személyig modellt” és a vizsgálattal rokonítható „személytől az ügyig modellt”. ${ }^{41}$

Bócz egy másik írásában - utalva Lakatos teóriájára - már felderítés és vizsgálat között tesz különbséget. A felderítést olyan tevékenységnek tekinti, amely a formális bizonyítás előkészítését célozza, (bizonyításra egyáltalán lesz-e szükség, mely tényeket kell majd bizonyítani). A vizsgálat alatt viszont a bizonyítási ok és tény valódiságának, közelebbi szemügyre vételét, tanulmányázását, értékelését érti, amely ekként jogilag szabályozott eljárási forma. Végső megállapítása pedig, hogy „[...] ha az igazság kiderítésére igény van, a bírósági eljárást előkészítő szakasznak a bizonyítékok felderítése mellett azok vizsgálata is szükségszerű fázisa”. Más kérdés viszont, hogy ennek „bírói vizsgálati” szintűnek kell-e lennie. ${ }^{42}$

${ }^{39}$ BallánÉ-Kunos-LaKatos (4. lj.) 92-106.; ugyanő hasonlóképp: Bócz (szerk.) (36. lj.) 126-129.

${ }^{40}$ Dobos János - Kovács Gyula: Kis nyomozástan (Budapest: Dr. Kovács Gyula $\left.{ }^{3} 2020\right) 71 ., 154$. Lakatos szerint ez az indokolatlan szükítés nem tudja megmagyarázni az ismert tetteses ügyekben az ismeretlen cselekményrész vagy az ismeretlen tettestársa irányadó adatgyűjtés helyét. Ô utal továbbá arra is, hogy sokan a felderitést a nyílt nyomozással szemben a titkos/operatív nyomozással azonosítják. Ld. LAKATos (3. lj.) 93.

${ }^{41}$ Doвоs-Kovács (40. lj.): 155-163. A szervezeti felosztást illetően valóban az látható, hogy mind a rendőrség, mind a NAV nyomozó szerveinél láthatunk külön vizsgálati, illetve felderítési (néha csak „bűnügyi”) nevű egységet (osztályt, alosztályt). Tudomásom szerint is változó, hogy a felderítő szervezeti egység a gyanúsítást követően vagy előtte átadja-e az ügyet a vizsgálati egységnek. (A felderítő szervek sokszor csak az adatgyűjtő, „operatív” feladatokra koncentrálnak.) A felosztás megjelenik a szolgálati beosztásokról szóló 30/2015. (VI.16.) BM rendelet által használt beosztási megnevezésekben is: pl. nyomozótiszt, vizsgálótiszt.

${ }^{42}$ Bócz Endre: Büntetőeljárási jogunk kalandjai (Budapest: Magyar Hivatalos Közlönykiadó 2006) 103-111. 


\subsection{AZ 1896. ÉVI XXXIII. TÖRVÉNYCIKK (I. BP.)}

Az I. Bp.-t a korszak eljárásjogászai tehát vegyes rendszerűnek tekintették, de csaknem minden jogtudós hangsúlyozza, hogy a törvény inkább (modern) vádrendszerű, mert többet merít e szisztémából, és az inkvizitórius elemek inkább az előkészítő fázisban jelennek meg. Ezzel együtt járt tehát az a megközelítés is, hogy a nyomozási/vizsgálati szakaszt (a pert, a bírósági eljárást) előkészítő eljárásnak tekintették és nevezték is. ${ }^{43}$ Ezt egyébként a törvény megnevezése is megerősíti, hiszen mindkét szava a vád alapján folyó bírósági perszakaszra utal. Sléder rámutat, hogy a korabeli szakirodalom is a perszakaszra koncentrált, és az előkészítő eljárás kevesebb figyelmet kapott, amely a szabályozási arányokban is meglátszik (a törvény csak tizennyolc szakasz erejéig szabályozza a nyomozást). ${ }^{44}$ Angyal például tankönyvében csak a „kir. törvényszék és az esküdtbíróság előtti eljárás” című részen belül, annak egyik (II.) fejezeteként elemzi az „Előkészítő eljárást”, amelynek további alcímei a nyomozás és a vizsgálat. ${ }^{45}$ Hasonló a didaktikai megoldás Finkeynél is, aki „A bűnvádi per előkészítése és lefolyása” cím alatt tárgyalja előkészítő eljárásokként a nyomozást és a vizsgálatot. ${ }^{46}$

$\mathrm{Az}$ I. Bp. tehát az előkészítő eljárás két fázisát ismeri: a nyomozást és a vizsgálatot. Vargha a törvény kommentárjában a kettéosztás okait külön is elemzi. A nyomozás jellemzője szerinte, hogy annak korlátlan ura az ügyész, de azt fő szabályként a rendőri hatóságok teljesítik. Az ügyész „dirigensi” szerepe a nyomozás befejezéséig tart, és ügyféllé válik, mihelyst vizsgálat elrendelését indítványozza. Utóbbi esetben a vizsgálóbíró irányában már utasítási joga nincs. A vizsgálat kapcsán kijelenti, hogy az már bírói eljárás, így azt megszüntetni sincs joga az ügyésznek, ezért a legmarkánsabb különbség a két szakasz között, hogy a vizsgálat megszüntetése res iudicatát jelent, míg a nyomozás megszüntetésének nincs ilyen következménye. Látszólagos különbség szerinte viszont a két szakasz eltérő törvényi célja (ld. később), mert valójában mindkét forma arra irányul, hogy az ügyész dönthessen arról, vádat emeljen-e, vagy nyomozás esetén a nyomozást megszüntesse, vizsgálat esetén pedig (mivel megszüntetésről csak a vizsgálóbíró dönthet) a vádat elejtse-e. Végül Vargha maga is felteszi a kérdést a kettős szabályozás szükségességéről. Arra jut - a vizsgálat kötelező esetei alapján -, hogy a bírói vizsgálat célja nem lehet más, mint garancia, hogy a legsúlyosabb bủncselekmények esetén mértékadó, bíróság által felvett bizonyításra kerüljön sor az anyagi igazság kiderítése cél-

${ }^{43}$ Pl. FInkey Ferenc: A magyar büntető eljárás tankönyve (Budapest: Politzer 1908) 215-218., AnGYAL (8. lj.) 253-258.

${ }^{44}$ SLÉDER Judit: A büntetőeljárás megindítása (Doktori értekezés 2010) 10-11. ajk.pte.hu/files/file/ doktori-iskola/sleder-judit/sleder-judit-vedes-ertekezes.pdf.

${ }^{45}$ Angyal Pál: A magyar büntetőeljárásjog tankönyve. II. kötet (Budapest: Atheneum 1917) 16. oldaltól.

${ }^{46}$ Finkey (42. lj.) 295. oldaltól. 
jából. Felhívja viszont a figyelmet, hogy míg a vizsgálat nehézkes és lassú, addig a nyomozás gyorsabb, ami lehetőséget ad a főtárgyalás mielőbbi megtartására, ezért az esetek többségében érdemesebb ez utóbbi módon lefolytatni az előkészítést. ${ }^{47}$

Uzonyi hasonló megállapításra jut, amikor kimondja, hogy az eltérő törvényi célok csak látszólagosak, „mert az elérni szándékolt eredmény [...] egy és ugyanaz”: van-e alap a vádemelésre, vagy nincs. A jogalkotói cél szerinte azt volt, hogy felszámolják a korábbi jogrend azon megoldását, hogy minden nyomozást vizsgálat kövessen, így csak a súlyos bűncselekmények esetén marad fent a kettőzöttség. ${ }^{48}$

Maga a törvény a nyomozás kapcsán azt mondja ki, hogy „A nyomozás tárgya: azoknak az adatoknak kipuhatolása és megállapitása, melyek a vád emelése vagy nem emelése kérdésében a vádló tájékozására szükségesek. A nyomozás e határon tul nem terjedhet.” (83. §) A törvényhely nézetem szerint három fontos pontot tartalmaz: a) a módot, b) a célt, és c) a határt. Az első momentum (a mód), hogy a törvény adatok kipuhatolásáról beszél, nem bizonyításról. A második pont (a cél) a vád emelése vagy nem emelése kérdésében való „tájékoztatása” a vádlónak. Vargha nézete, hogy a vád nem emelése (itt csak ez jöhet szóba, a vád elejtése még nem) a legalitás parancsa folytán nem mérlegelhető a vádló által („,az ügyészt opportunitási okok nem vezethetik”), így a „vád nem emelésének” - a büncselekmény hiányának, vagy törvényi feltételek hiányának esetén kívül (101. § 1. és 2. pontok) - csak egy mérlegelhető esete van: „a bizonyítékok megszerzésének rendkívüli nehézsége” (101. § 3. pont). ${ }^{49}$ A harmadik lényeges kitétel pedig a határ, azaz, hogy ezen „mélységen” a nyomozás nem terjedhet túl. Vargha szerint utóbbi rendelkezés azt célozza, „Nehogy a nyomozás terjengős legyen”, ezért mihelyst az ügyész a beszerzett adatokból „képes magát tájékoztatni”, a nyomozás „az eredményhez képest, vagy megszüntetendő, vagy befejezendő" ${ }^{50}$ Mindazonáltal a nyomozás nem jelenthetett puszta adatgyüjtést, mert a 96. § felhatalmazta a rendőri hatóságokat, hogy bárkit kihallgassanak (erről jegyzőkönyvet vegyenek fel), és engedte a törvény X. és XIII. fejezetében írt intézkedések (a terhelt és a tanúk kihallgatásának részletes szabályai) alkalmazását. A 98. § pedig - bár bírói engedéllyel, vagy halaszthatatlan esetben enélkül is - lehetővé tette a szemle, lefoglalás, motozás, házkutatás elrendelését is a rendőrhatóságoknak a nyomozás során is.

Rédey a fenti szabályozásról meg is jegyzi, hogy „a törvény végrehajtásának első hetében bebizonyult azonban, hogy a nyomozatoknak ilyen szük korlátok közé szoritása merőben tarthatatlan”. Egy belügyminiszteri rendelet ${ }^{51}$ ezért azt írta elő, hogy „a nyomozás feladata a tényálladékra vonatkozó adatoknak olykép való összegyűjtése, hogy azok alapján a birósági vizsgálat lehetőleg mellőzhető s az ügy közvetlenül az itélő biróság elé vihető legyen”. Így „az év végére odáig fejlődött a nyomozás, hogy

${ }^{47}$ Balogh-Edvi IllÉs-VARgha II. (14. lj.) 1-6.

48 Uzonyi Géza: „A nyomozás és a vizsgálat czélja az uj bünvádi perrendtartásban” Jogtudományi Közlöny 1898/15. 116.

${ }^{49}$ BAlogh-Edvi IllÉS-VARgha II. (14. lj.) 8.

50 BALOGH-Edvi IllÉs-VARgha II. (14. lj.) 8.

51 130000/V.B.1899. számú Bel. Min. rendelet 3. §-a. 
valóságos vizsgálattá lett”. ${ }^{52}$ Részben hasonló gyakorlati kérdést feszeget Bodor, aki azt a törvényszövegben megjelenő, ám ezzel rendeleti szinten ellentétes anomáliát részletezi, hogy a nyomozások során a rendőrségnek csak egyes egységei voltak feljogosítva tényleges kihallgatási és jegyzőkönyvezési joggal, így a rendőri szervek nagy része legfeljebb összefoglaló tényvázlatot tudott átadni az ügyészségnek. ${ }^{53}$ Ugyanígy a rendőri közegek nyomozási jogosultságairól (és képességeiről) ír Kármán is. ${ }^{54}$

Az. I. Bp. 102. §-a pedig már a vizsgálat fogalmáról szól: „azoknak az adatoknak birói kideritése és megállapitása, melyek alapján eldönthető, hogy van-e helye a főtárgyalás elrendelésének, vagy hogy meg kell-e szüntetni a bűnvádi eljárást. A vizsgálat az e czél szabta határokon tul nem terjedhet." Itt is jól elkülöníthető a három szempont (mód, cél, határ). A vizsgálat módja tehát nem adatok kipuhatolása, hanem adatok kiderítése (a megállapítás szó azonosan szerepel). Vargha mégis úgy véli, hogy e kitételek tartalmilag teljesen azonosak a nyomozásnál meghatározott kifejezésekkel. ${ }^{55} \mathrm{~A}$ módbeli eltérés tehát alapvetően az alany, tehát a bíró személyében állt fenn. A cél hasonló, de mégis eltérő a nyomozástól: azt kell tudni eldönteni az adatok alapján, hogy helye lehet-e fötárgyalásnak vagy meg kell-e szüntetni az eljárást. Ahogy korábban írtam, Vargha szerint ez összességében szintén a vádemelésröl való döntést jelenti, hiszen vizsgálat esetében is az ügyész volt a vádemelő. A határt tekintve viszont a megfogalmazás azonos a nyomozásnál írtakkal, azzal, hogy itt a konkrét ügybeli határt (befejezhető-e a vizsgálat) csak a vizsgálóbíró húzhatta meg. A törvény 117-127. §-ai a vizsgálat menetét részletezik, amelyből az derül ki - annak kikötésével, hogy a nyomozás eljárási cselekményei csak kivételesen ismételhetőek meg -, hogy a vizsgálóbíró minden érdemi bizonyítási cselekményt elvégezhetett (a terhelt és a tanúk kihallgatása, szemle lefolytatása stb.) a „való tényállás megállapítása" érdekében, amelyeket jegyzőkönyvben kellett rögzíteni.

\subsection{AZ 1951. ÉVI III. TÖRVÉNY (II. BP.)}

A szocialista korszak jogtudománya jóval fontosabb - több mint előkészítő - szerepet szánt a nyomozásnak. Ez jól megragadható a törvény rendelkezéseiben is, sőt, az idő előrehaladtával a nyomozás szabályai egyre részletgazdagabbak lettek. Bólya a nyomozást olyan tevékenységként definiálja: „[...] amelynek során biztosítják a bűncselekmény nyomainak összegyűjtését és megőrzését, a tanúk és szakértők előadásából származó bizonyítékok rögzítését, a tettes személyének megállapítását [...]”. Külön is hangsúlyozza, hogy a szocialista jogrendben „új nyomozás fejlődött ki”, amely „nem hasonlít a burzsoá büntetőeljárás hasonló nevű intézményéhez”. A nyomozás egyik elveként pedig a „teljességet” vagy „alaposságot” határozza meg, amely szerint a bűncselekményeket „a legteljesebb alapossággal minden irányban fel kell deríteni”, tehát „minden bizonyítékot be kell szerezni”, amelyeket

${ }^{52}$ RÉdey Miklós: A nyomozási eljárás nehézségei (Budapest: Légrády Testvérek 1901) 9-11.

53 Bodor László: „Rendőri nyomozás” Jogtudományi Közlöny 1900/7. 52-53.

${ }^{54}$ KÁRMÁN Elemér: „A csendőri nyomozás reformja” Jogtudományi Közlöny 1910/16. 133-135.

${ }^{55}$ BALOGH-Edvi IllÉS-VARgha II. (14. lj.) 51. 
„[...] megfelelő okmányokkal kell alátámasztani: [...] jegyzőkönyvekkel, szakértői véleménnyel stb." 56

A II. Bp. már hosszabban, önálló fejezetben, és már a későbbi kódexekhez hasonlóan a különös/dinamikus rész kezdő fejezeteként, az általános/statikus szabályokat követően tárgyalta a nyomozás szabályait. E törvény már nem tartotta fenn a nyomozás-vizsgálat kettősségét, egységesen nyomozást szabályoz. A VI. fejezetnek már a címe is eligazít az eljárási szakasz helyét illetően: „Az eljárás megindítása - Nyomozás”. Ehhez képest a miniszteri indokolásban még mindig megjelenik az „előkészítő szak” kifejezés (bár a nyomozás szerepe kapcsán további megállapításokat nem tesz). A törvény 1954. évi novellája ${ }^{57}$ azonban jelentősen átalakított ezt a fejezetet is. Bócz egyébként úgy látja, hogy míg a II. Bp. eredeti szövege a nyomozásnak kevésbé hangsúlyos szerepet szánt, addig a novella lényegében visszavezette az I. Bp. szerinti (a bizonyítás szempontjából igen alapos) vizsgálati szakasz megoldásait, így ezzel a nyomozás a tárgyalással egyenrangú főszakasszá vált. ${ }^{58}$

A nyomozás fogalma kapcsán az eredeti szöveg semmit nem tartalmazott, de a novellát követően is csak formai követelményt (határozattal való megindítás) rögzített [86. § (1) bekezdés]. Ennél többet mond „A nyomozás teljesítése” cím alatti rendelkezés (a módosítás előtt is hasonlóan), amely szerint „A nyomozás teljesítése során gondoskodni kell az elkövető kilétének megállapításáról, szökés veszélye esetén annak megakadályozásáról, a terhelt és a tanúk kihallgatásáról, a tárgyi bizonyítékok megszerzéséről és biztosításáról, szükség esetén szemle tartásáról, szakértő meghallgatásáról, valamint az eljárás sikeréhez egyébként szükséges körülményeknek más alkalmas módon való felderítéséről.” A tartalmat tehát a nyomozás keretében tipikus eljárási cselekmények felsorolásával adta meg. Mindazonáltal a jogszabály kommentárja egyértelműsíti, hogy ez csak példálózó felsorolás. ${ }^{59}$

Nem láthatunk viszont itt kifejezett célt, módot vagy határt megjelölve. Annyi mindenesetre bizonyos, hogy a felsorolt eljárási cselekményekre lehetőség volt, amelyek nagyobb része egyértelműen a bizonyítás területére esik. Ezt erősíti a későbbi törvények által is követett szabályozási megoldás, miszerint a nyomozásról szóló fejezet megismétli, és a nyomozásra alkalmazandóan részletezi egyes, a bizonyításra vonatkozó statikus jogintézmények (pl. a terhelt, a tanú kihallgatása, szakértők, szemle stb., sőt e törvény esetében még egyes kényszerintézkedések) szabályait.

A nyomozásról szóló fejezet egyik utolsó címe ad talán némi eligazítást a nyomozás valódi céljáról és szerepéről. „A nyomozás befejezése” a törvény eredeti szöve-

${ }^{56}$ BóLya Lajos - Kocsis Mihály - MóRa Mihály: Büntető eljárási jog II. kötet. (Budapest: Felsőoktatási Jegyzetellátó 1954) 230-231., 248.

57 1954. évi V. törvény 21-26. §-ok.

${ }^{58}$ Bócz (41. lj.) 35-40. Bócz szerint az olyan jogintézmények, mint a nyomozás határozattal való lezárása, a pótmagánvád kiiktatása, az ügyész nélküli tárgyalás bevezetése, a feljelentés kiegészítésének beiktatása mind a nyomozási szakasz hangsúlyosabbá válására utalnak. Máshol megjegyzi, hogy a hazai nyomozás lényegében a szovjet jogban a nyomozást kötelezően követő (és perrendszerü bizonyítást megkövetelö) vizsgálat átvételét jelentette, illetőleg a magyar nyomozásban végül összeolvadt az eredetileg rendőri (adatgyűjtő, felderítő) nyomozás és a bírói (bizonyító) vizsgálat. Bócz Endre: „Adatgyűjtés, felderítés, nyomozás” Belügyi Szemle 2011/4. 67., 71.

${ }^{59}$ MolnáR László és munkaközössége: A büntető perrendtartás kommentárja (Budapest: KJK 1957) 263. 
gében még azt tartalmazta, hogy „A nyomozást be kell fejezni, ha annak eredménye szerint a vádirat benyújtására kellő alap van” [135. § (1) bekezdés]. A novellát követően azonban már az szerepelt, hogy „A nyomozóhatóság, ha a tényállást felderítette és a terhelt bünösségének megállapításához szükséges adatokat megszerezte, a nyomozás befejezéséről határozatot hoz." E szabályokból már jobban kiolvasható a nyomozás célja, egyben határa is, de míg a korábbi szöveg inkább az I. Bp.-hez hasonlókat ír elő, addig a későbbi rendelkezésből már a teljes felderítettségre, sőt bizonyítottságra való törekvés tűnik ki. Ezzel kezdődött meg jogszabályi szinten is az a tendencia, amely a nyomozásra is a teljes körü, a bírósági szakaszhoz hasonló (azzal egyenértékủ, ún. perrendszerü) bizonyítást követelte meg.

Ezt erősíti a jogszabályhoz füzött kommentár is, amely egyrészt hangsúlyozza, hogy a fenti rendelkezés „az objektív igazság elvének érvényesítését jelenti”, másrészt külön felhívja a figyelmet arra, hogy a novella újítása „nem pusztán szövegezési módosítás”, hanem „nagyjelentőségű elvi állásfoglalás”. Az új szöveg ugyanis kifejezésre juttatja, hogy „a büntetöügy összes körülményeit a nyomozás befejezése előtt a valóságnak megfelelően fel kell deríteni”, míg a korábbi szöveg alapot adott arra a törvénysértő gyakorlatra, amely szerint a nyomozás befejezhették a teljes felderítettséget megelőzően, ha már elegendő adat volt a vádemelésre. ${ }^{60}$

Egy dolgot még meg kell említeni: a II. Bp. a novelláris változtatást követően mégiscsak beépített egy határt szabó rendelkezést, ugyanis rögzítette a nyomozás határidejét is (ezt egy hónapban határozta meg, amely az ügyészség által hosszabbítható volt). ${ }^{61}$ Azt azonban e törvény kapcsán még csak a kommentár mondta, ki, hogy „a nyomozást - teljes alaposság és tárgyilagosság mellett - a legrövidebb időn belül teljesíteni kell. ${ }^{62}$

\subsection{AZ 1962. ÉVI 8. TVR. (I. BE.)}

Az I. Be. - Farkas szavaival - „nem új jogalkotási produktum. Szövegének mintegy kétharmada azonos a korábbi törvényével, és a törvény szerkezete sem változott meg", ${ }^{63}$ így csak az érdemi eltérésekre szükséges felhívni a figyelmet.

A korszak egyik szakkönyve szerint a bűntetőeljárás főbb szakaszai a nyomozás és a bírói eljárás, előbbi alatt értendő a tényállás kiderítése, a bizonyítékok beszerzése,

${ }^{60}$ Molnár (56. lj.) 346.

61 Jól kimutatható az összefüggés a nyomozás „mélysége” és a nyomozás határideje között. Szabó mutat rá, hogy „amennyiben a nyomozás során a tényállás teljes körū megállapítása, perrendszerű bizonyítékok összegyűjtése a cél, úgy ez bonyolultabb, összetettebb tevékenységet igényel az eljáró hatóságok részéről, amelyet figyelembe kell venni a nyomozási határidő törvényi szabályainak kidolgozásánál. Amennyiben viszont a bizonyítás súlypontját a büntetőeljárás tárgyalási szakára, azon belül elsősorban az elsőfokú tárgyalásra helyezzük, úgy egy kevésbé formális, nem perrendszerű bizonyítást lefolytató nyomozás rövidebb határidőn belül is lefolytatható.” SzABó Krisztián: „Gondolatok a nyomozás határidejére vonatkozó kodifikációs elképzelésekről” Jura 2016/1. 316. Kiss pedig a nyomozások (általában az eljárás) elhúzódásának egyik okaként épp a túlbizonyítást jelöli meg. KIss Anna: „A hazai büntetőeljárás hatékonyságáról” Kriminológiai tanulmányok 53. 2016. 84.

62 Molnár (56. lj.) 265.

${ }^{63}$ FARKAS-Róth (8. lj.) 66. 
összegyűjtése és biztosítása, az elkövető személyének felderítése. Mindez egyben a „bírói eljárás szakának előkészítését jelenti”. Egy másik helyen ugyanezen írás ismét azt rögzíti, hogy a nyomozás célja „a tényállás felderítése és a tettes bünösségének megállapításához szükséges adatok megszerzése”, azonban a nyomozás feladataként jelöli meg, hogy „elökészíti a bíróság igazságszolgáltató tevékenységét”. Később azonban a mű világossá teszi a nyomozás teljessége elvének kibontásánál: „A büntetőügy minden apró részletét fel kell deríteni, ami a bírósági tárgyalás során felmerülhet”. ${ }^{64} \mathrm{Ne}$ tévesszen meg tehát senkit az előkészítő szó újra felbukkanása, hiszen az I. Be. semmiképpen sem az I. Bp. elveit kívánta restaurálni. Figyeljünk fel inkább arra, hogy ez az előkészítés már nem a vád, hanem a bírósági ítélkezés előkészítését jelentette, tehát a bíróság „előre ellátását” olyan bizonyítékokkal, amelyre az ítélkezésnél támaszkodhat.

Az eljárási szakaszok hierarchiáját illetően Szabóné is egy, az eljárás egységét valló koncepciót fejt ki, amely nem engedi meg a perszakasz kizárólagosságát, és a nyomozás kisegítő jellegét. Ezért is látja úgy az eljárás rendszerét illetően, hogy abban a nyomozási szakaszt is meghatározóan figyelembe kell venni, és az eljárás alapelveit és garanciáit a nyomozási szakaszt illetően is meg kell valósítani. ${ }^{65}$

A tvr. miniszteri indokolása rámutat, hogy a jogszabály elnevezése már nem perrendtartás, mert „az eljárásjogi kódexnek nemcsak a büntetőeljárás bírói szakaszát kell szem előtt tartania, hanem egyenlő súllyal az egész eljárást, annak elrendelésétől, tehát a nyomozás megindításától kezdve [...]”. A nyomozás teljesítése cím alatt (110. §) a jogszabály megismétli a II. Bp.-nél idézett feladatokat, amelyet kiegészít azzal is, hogy a nyomozás során fel kell deríteni a törvény 168. § (1) bekezdés b) pontjában írt körülményeket is, amely nem más, mint a vádirat egyik tartalmi kelléke. ${ }^{66}$ A tvr. tehát a felderítendő körülményeket a vádirat tartalmi elemeihez igazítja, így még pontosabb tényfeltáró tevékenységet várt el a nyomozást teljesítő hatóságtól.

Az I. Be. kapcsán meg kell még említeni, hogy novellája (az 1966. évi 16. tvr.) 110/A. §-ként beiktatta az ún. egyszerűsített nyomozás ${ }^{67}$ lehetőségét: „Az olyan bűntettek miatt, amelyekre a törvény egy évi szabadságvesztésnél nem súlyosabb büntetést rendel, továbbá járásbírósági hatáskörbe tartozó olyan egyéb bủntettek miatt is, amelyek felderítése, valamint ténybeli és jogi megítélése egyszerű, amenynyiben a feljelentés és az ahhoz csatolt bizonyítékok, így [...] más eljárás iratai alapján a büntett elkövetése és az elkövető kiléte megnyugtatóan bizonyítottnak látszik,

${ }^{64}$ A büntető eljárás kézikönyve I. (Budapest: BM Tanulmányi és Módszertani Osztálya 1963) 171., 212., 219. (A mű szerzők nevét egyáltalán nem tünteti fel.)

65 SzabónÉ NAGY Teréz: A büntetőeljárási rendszer alapjai (Budapest: KJK 1966) 35-37. 243-261. Később Szabóné ugyanígy: SzABóNÉ NAGY Teréz (szerk.): Magyar büntető eljárási jog. I. Egységes jegyzet (Budapest: Tankönyvkiadó 1986) 94-97., illetve RudAs György (szerk.): Büntetőeljárásjog (Budapest: BM Tanulmány és Propaganda Csoportfőnökség 1974) 57-59.

${ }^{66}$ A vádiratnak tartalmaznia kellett: a tényállás rövid előadását a bűntett elkövetési helyének és időpontjának, módjának, indítékainak, következményeinek és egyéb lényeges körülményeinek megjelölésével, továbbá a bűntett és az elkövető társadalomra veszélyességének megítéléséhez szükséges személyi, illetve tárgyi körülményeket.

${ }^{67}$ A jogirodalomban pl. Herke is felveti az ún. bagatelleljárások bevezethetőségét, amely más jogrendszerekben is ismert, elkülönült szabályokból álló eljárási forma. HERKE Csongor: „Súlyosítási tilalom a nyomozási szakban?" Rendészeti Szemle 2010/3. 62-64. 
a nyomozás elrendelése után csak a terheltet kell kihallgatni.” Itt tehát ismét megjelent egyfajta osztottság a nyomozás módozatait illetően, amely ugyan nem szakaszokra bont, hanem egyes ügytípusoknál egyszerübb formát tesz lehetővé, mintegy kivételt engedve a szigorú „teljesség” elve alól.

\subsection{AZ 1973. ÉVI I. TÖRVÉNY (II. BE.)}

A II. Be. miniszteri indokolásából egyrészt a nyomozás szerepének további erősödése (pl. terhelti és védői jogok szélesítése a nyomozás során), másrészt viszont az egyszerüsítésre törekvés is kiolvasható (pl. a terheltté nyilvánító határozat elvetése, a vétségi nyomozás bevezetése). Érdekes módon épp a funkciómegosztás elve kapcsán említi az indokolás, hogy az „hủen tükrözi a büntetőeljárás egységét, [...] az eljárás nyomozási szakaszának valóságos jelentőségét [...]”.

Már a törvény alapelvei között találhatunk a nyomozás „mélységére” vonatkozó szabályokat. Egyrészröl a törvény több elv esetében a büntetőeljárásban eljáró „hatóságokról” beszél, amiről tudjuk a II. Fejezet azonos elnevezése alapján, hogy az a nyomozó hatóságot is jelentette. Az alapelvek között pedig az 5. §-ban megjelenik az anyagi igazság elvének deklarálása (ez a későbbi kódexekben már a bizonyításról szóló fejezetekben szerepel), amelynek kapcsán a törvény kimondja, hogy „a hatóságok feladata, hogy az eljárás minden szakaszában a tényállást alaposan és hiánytalanul tisztázzák, a valóságnak megfelelően állapítsák meg”. Világos ez alapján, hogy a nyomozás során a nyomozó hatóságoknak is az anyagi igazság elérésére kellett törekedniük. Ezt megerősíti a törvény kommentárjában Szabóné, aki szerint a nyomozó hatóságnak is a tényállás alapos tisztására kell törekedni, amely azt jelenti, hogy a hatóságoknak a megállapításaikat bizonyítékokra kell építenie, és bizonyítékokkal kell alátámasztania (bár azt is jelzi, hogy a túlbizonyítás nem kívánatos). ${ }^{68}$ Kratochwill szintén azt állapítja meg a nyomozás kapcsán, hogy a nyomozás alaposságának igénye kétirányú: egyfelől a bizonyítás sokoldalúságát és teljességét, másfelől a bizonyítás megalapozottságát jelenti. ${ }^{69}$

A törvényszöveg maga a nyomozást vagy annak feladatát már nem definiálja. Az eljárás alanyairól szóló fejezetben, a nyomozó hatóság feladataként rögzíti viszont a törvény a bűncselekmények gyors és alapos felderítését, valamint a bűncselekmények elkövetőinek felelősségre vonásához szükséges eljárási cselekmények elvégzését (16. §). A törvény kommentárjában Gödöny a nyomozás funkcióját tekintve elsőre ellentmondásosnak tűnő megállapítást tesz: az állítja, hogy „A nyomozás a büntető eljárás előkészítő szakasza”, majd nyomban ezután azt mondja, hogy „a nyomozás a bírósági eljárás mellett a büntetőeljárás másik fő szakasza”. Az ellentmondást akként oldja fel, hogy szerinte a nyomozás, ha azt sokoldalúan, teljesen és tárgyilagosan folytatják le, lehetővé teszi, hogy a bíróság helyesen bírálja el az ügyet,

${ }^{68}$ LÁszLó Jenő (szerk.): A büntető eljárás magyarázata (Budapest: Közgazdasági és Jogi Könyvkiadó 1982) 31.

${ }^{69}$ SzabónÉ Nagy Teréz (szerk.): Magyar büntetö eljárási jog. II. Egységes jegyzet (Budapest: Tankönyvkiadó 1987) 26. 
tehát a nyomozás célja a bírósági eljárás „megfelelő” előkészítése, merthogy a nyomozás során „a bizonyítás törvénynek megfelelő teljesítésével, a szükséges eljárási cselekmények elvégzésével biztosítja az alapot a bírósági eljáráshoz” ${ }^{70}$ Látni kell tehát, hogy hiába az „előkészítő” jelző, a szövegmagyarázat a nyomozást főszakasznak tekinti, amely nem a vád, hanem a bírósági eljárás megalapozását szolgálja, méghozzá bizonyítás lefolytatása révén. Szabóné a nyomozást szintén az eljárás „főszakaszának” titulája. ${ }^{71}$

A nyomozás teljesítése cím alatt (131. §) az eredeti szövegben csak a nyomozás határidejére vonatkozó szabályokat találhatjuk, és a nyomozás befejezésénél sem szerepelt tartalmi meghatározás (142. §), ám a törvény 1987. évi novellájával ${ }^{72}$ egy fontos, rendelkezés került be: „A nyomozás során a valóságnak megfelelő tényállás felderítése érdekében haladéktalanul meg kell tenni minden törvényes és célszerủ intézkedést”. Ebben van tehát egy időbeliségre utaló kritérium, ám az első mondat a korábban már idézett alapelvi tételt (5. §) ismétli meg.

A II. Be.-ben már következetesen érvényesült, hogy a bizonyításra vonatkozó általános szabályok a statikus/általános részben, a IV. fejezetben jelennek meg, ekként azok valamennyi (dinamikus) eljárási szakaszban, így a nyomozás során is alkalmazandók. Ebböl, és az alapelvek között rögzített szabályból is következik, hogy a nyomozás során is a teljes körü, a bírósági eljárással egyenértékű („perrendszerü”) bizonyításfelvétel volt az irányadó (pl. tipikusan tanúkihallgatások, szakértő kirendelése). A nyomozási szakasznál ehhez képest csak néhány, az adott eljárási szakasz természetéből adódó kiegészítő szabály szerepel (VI. fejezet I. cím).

A már említett vétségi eljárás nyomozás során alkalmazandó szabályait a VI. fejezet, II. címe alatti vétségi nyomozás jelenítette meg. A vétségi eljárást a 90 . § (1) és (2) bekezdésének szabályai szerint alapvetően (kivételekkel) vétségek, és legfeljebb 3 évig terjedő szabadságvesztéssel büntetendő bűntettek esetében lehetett alkalmazni. A nyomozás kapcsán a legjelentősebb egyszerűsítő rendelkezés az volt, hogy a tanúkihallgatásról és más nyomozási cselekményekről jegyzőkönyv helyett jelentést is elegendő volt készíteni (150. §). A törvény kommentárja szerint ez nemcsak az egyszerűsítést, hanem a gyorsítást is célozta, továbbá a jelentés az alakszerűséghez kötött írásbeliség csökkentését is. Mindemellett azonban a magyarázat felhívja a figyelmet arra, hogy a vétségi nyomozást is „éppoly körültekintően, alapossággal és objektivitással kell lefolytatni”. ${ }^{73}$

\subsection{AZ 1998. ÉVI XIX. TÖRVÉNY (III. BE.)}

A III. Be. jelentős határvonal (lett volna) a nyomozás jövőjét, koncepcióját illetően. A kódex megalkotásakor egyre többször vetődött fel egyes angolszász megoldások átvételének gondolata (pl. felek általi kihallgatás), és az is, hogy szakítani kell a nyo-

70 LÁsZló (szerk.) (65. lj.) 379.

71 SzABóné (szerk.) 1986 (62. lj.) 46.

72 1987. évi IV. törvény 22 . .

${ }^{73}$ LÁszLó (szerk.) (65. lj.) 474-475. 
mozás és a tárgyalás egyenrangú szakaszokként való felfogásával, és a tárgyalás központi, míg a nyomozás előkészítő szerepét kell hangsúlyozni. ${ }^{74}$ Ezt erősítik a miniszteri indokolásban lefektetett tételek, amelyek szerint: „Olyan eljárást kell kialakítani, amelyben [...] a büntetőjogi felelősség kérdése a közvetlenség elvének tiszteletben tartásával a tárgyaláson dől el [...].” Még egyértelmübb azonban az a megállapítás, miszerint „[... [ az eljárás két fő szakasza közti kapcsolatot a törvény a nyomozás és a bírósági eljárás egyenrangúságának „szocialista” elmélete helyett a Bp.-hez hasonlóan határozza meg. A nyomozás feladata eszerint a vád előkészítése [...]”.

Utóbbi megközelítés a törvényszövegben is megjelenik a nyomozás feladataként: „A nyomozás során fel kell deríteni a bűncselekményt, az elkövető személyét, fel kell kutatni és biztosítani kell a bizonyítási eszközöket. A tényállást oly mértékben kell felderíteni, hogy a vádló dönthessen arról, vádat emel-e.” (164. §) Katona szerint ez a száz évvel korábbi megfogalmazás újramegjelenítése. ${ }^{75}$ Király megállapítása szerint pedig: „Ez a rendelkezés, ha a gyakorlatban megfelelően alkalmazzák, jelentékeny befolyással lehet a nyomozás eljárásbeli helyének és terjedelmének meghatározására. Kifejezi ugyanis a nyomozásnak és a vádnak azt a viszonyát, amelyben a vádemelés feltételei a nyomozás számára iránymutatásként szolgálnak”. Úgy látja továbbá, hogy „értelme az is, hogy a bizonyítást ésszerűen meghatározott mederben kell tartani, vagy a „túlbizonyítást” el kell kerülni”. ${ }^{76}$

A már említett anyagi igazság elvét többször is ilyen nevén említi az indokolás, ott azonban, ahol e kérdés a legjelentősebb, azaz a bizonyítás szabályainál, a törvény eredeti szövege még nem tartalmazott erre vonatkozó rendelkezést. Csak a törvényt még a hatálybalépése előtt módosító 2002. évi I. törvény nyomán került be a 75. § (1) bekezdés 2. mondataként az a szövegrész, miszerint „A bizonyítás során a tényállás alapos és hiánytalan, a valóságnak megfelelő tisztázására kell törekedni”. Arra is érdemes felfigyelni, hogy a bizonyítékok értékelését előíró 78. § (3) bekezdésének a címzettje kizárólag a bíróság és az ügyészség volt egészen a törvény hatályáig, valamint a II. Be.-vel ellentétben az anyagi igazság címzettjeit sem jelöli meg olyan világosan a III. Be.

A III. Be. sokak által üdvözölt, felderítésre irányadó rendelkezései voltak az ún. puhatolás szabályai. ${ }^{77} \mathrm{Az}$ eredeti törvényszöveg még kifejezetten úgy fogalmazott

74 Bócz számos írásában ennek adott hangot. Pl. Bócz Endre: „A nyomozási szakasz néhány alapkérdése az új büntetőeljárási törvényben” in TóTH Mihály (szerk.): Büntető eljárásjogi olvasókönyv (Budapest: Osiris 2003) 304-306.; vagy Bócz Endre: „,Megismerés” és „bizonyítás” a büntetőeljárásban” in Tóтн Károly (szerk.): Emlékkönyv dr. Cséka Ervin egyetemi tanár születésének 70. és oktatói munkásságának 25. évfordulójára (Szeged: JATE 1992) 83-96. Utóbbi írásában azt mondja, hogy a nyomozás során csak megismerésnek, és a bizonyítás előkészítésének, az arra való alkalmasság megvizsgálásának kellene folynia (uo. 94-95.). Tremmel és szerzőtársai a III. Be. idején készült legutóbbi tankönyvükben már „A büntetőeljárás előkészítő szakasza” címmel jelölték a nyomozásra vonatkozó ismeretanyagot. Herke Csongor - Fenyvesi Csaba - Tremmel Flórián: A büntető eljárásjog elmélete (Budapest-Pécs: Dialóg-Campus 2012) 223-251.

75 Katona Géza: „Időutazás a nyomozás körül” in Tóth Mihály (szerk.) Büntető eljárásjogi olvasókönyv (Budapest: Osiris 2003) 301.

${ }^{76}$ KIRÁly Tibor: Büntetőeljárás jog (Budapest: Osiris 2003) 316-317.

77 Pl. Bócz 2003 (70. lj.) 306.; vagy Tremmel Flórián: „A gyanú differenciált felmerülésének értékelése a büntetőeljárásban” in Tóтн Mihály (szerk.) Büntető eljárásjogi olvasókönyv (Budapest: Osiris 
a 178. § (1) bekezdésében, hogy „A nyomozó hatóság a büntetőeljárás megindítása után annak megállapítására, hogy vannak-e bizonyítási eszközök, és ezek hol találhatók, puhatolást végezhet, ennek során információt gyüjthet, felvilágosítást kérhet, iratokat megtekinthet, a bủncselekmény helyszínét megtekintheti, szaktanácsadót vehet igénybe, és a megszerzett adatokat ellenőrizheti." Ezt a (3) bekezdés szerint jelentésbe kellett foglalni. Ez lényegében a kriminalisztikai értelemben vett felderítés megjelenítése volt. Maga az indokolás is a puhatolást „informális” jogintézménynek tekinti. Végül azonban a 2003-ban hatályba lépett szövegében már a puhatolás szó sem jelent meg, csak a hasonló, de bővebb tartalmú adatszerző tevékenység. Úgy tűnhet azonban, hogy a puhatolás egy kevésbé körülírt felderítő tevékenységet takart volna, míg az adatszerzés szabályai részletesebbek és konkrétabbak. A módosító 2002. évi I. törvény indokolása azonban csak annyit füz ehhez, hogy az „eredeti szóhasználatában szereplő „puhatolás” szót - archaikus volta miatt - s mellőzi a szövegből, ehelyett az „adatszerzés” kifejezést használja, amely világosabb. Azt azonban ezen indokolás is kifejezésre juttatja, hogy „Az új (1) bekezdés szerinti cselekmények elvégzéséhez a nyomozó hatóságnak nincs szüksége ügyészi engedélyre vagy hozzájárulásra: ezek olyan intézkedések, amelyek a kriminalisztika körébe tartoznak, és jogilag kevéssé szabályozhatóak.”

Végül a III. Be. kapcsán még egy egyszerűsítést célzó szabályt kell megemlíteni. Az eredeti szöveg 168. §-ának elöírásai megengedték, hogy valamennyi nyomozási cselekményekről jegyzőkönyv helyett jelentés készülhessen. Ez az indokolás szerint „Az eljárás gyorsítását, a fölösleges alakiságok és bürokratikus elemek csökkentését célozza [...]”. E szakasz (2) bekezdése egyértelműsítette azt is, hogy ez alatt nemcsak a tanú-, de a gyanúsítotti vallomás is értendő: „A gyanúsított és a tanú kihallgatásáról készült jelentés tartalmazza a vallomás lényegét." Nézetem szerint ez is az egyszerübb, angolszász típusú nyomozás felé való közeledést célozta volna, egyben megfelelt volna a 164. § idézett rendelkezésének, amit az indokolás is megerősít: „Az eljárási cselekmények jelentésbe foglalását tekinti a törvény a főszabálynak [...]. Az egyszerübb jelentés éppúgy alkalmas a vádló tájékoztatására, mint a jegyzőkönyv." E szöveg sem maradhatott azonban hosszú életű, sőt, a gyakorlatban sosem vert gyökeret. Az ügyészi szervezet már az elejétöl fogva idegenkedett, különösen a gyanúsítotti vallomás esetében a jelentés lehetőségétől. A 11/2003. (ÜK.7.) LÜ utasítás 31. § (2) bekezdése ugyanis lefektette, hogy „Az ügyész a megalapozott gyanú közléséről, a gyanúsított ezzel összefüggő kihallgatásáról, továbbá a megítélése szerint az ügyben meghatározó jelentőségű, általa megjelölt egyéb eljárási cselekményekről jegyzőkönyvet készít, illetőleg készíttet.” A Legfőbb Ügyészség a Be. alkalmazásának egyes kérdéseiről kiadott ún. Emlékeztetőjének korai szövege ${ }^{78}$ pedig a 229. pontban azt írta elő, hogy „A gyanúsított vallomásáról akkor készíthető jelentés, ha az a terhére rótt cselekménnyel nem függ össze." A hatálybalépéstől azonban még egy ideig a fenti formában élt e szövegrész, mert csak a 2006. évi novel-

2003) 397. Bócz egyébként ezen adatgyüjtést - „puhatolást” - azonosítja a valódi felderítéssel, sőt úgy látja, hogy valójában még akár nagyobb ügyekben is elegendő lehet ez a vádemeléshez, de akár az ítélethozatalhoz is. Bócz 2011 (55. lj.) 74-76., 78.

78 Megjelent az Ügyészségi Közlöny 2004/1. számában. 
lával ${ }^{79}$ tünt el a törvényből (nyom nélkül, mert e törvény indokolása erre egyáltalán nem utal). A 2007. évi XXVII. törvény viszont egyértelműsítette a helyzetet azzal a rendelkezéssel, hogy „A gyanúsított és a tanú kihallgatásáról, illetőleg a szembesítésről jelentés nem készíthető.” E törvény indokolása szerint bár a 2006. évi novella hatályon kívül helyezte a jelentés lehetőségét, azonban szükség volt e szöveggel minden kétség kizárni.

A III. Be. idején végül sem az ügyészség sem a nyomozó hatóság részéről nem volt elfogadható az áttérés a nyomozásnak egy egyszerűbb, adatgyűjtő formájára. ${ }^{80}$ Érdekes módon azonban a bíróság - amely, ha mondhatjuk úgy mindig is kimaradt a nyomozás folyamatából, és csak annak eredményét láthatta - mindvégig egy kevésbé jelentős szakasznak tartotta a nyomozást. Bár tény, hogy a bíróság a mai napig döntéseinél (és nem csak azon esetekben, amikor a tényleges tárgyalás elmarad) erőteljesen épít a nyomozás bizonyítékaira, egyes eseti döntések mégis a nyomozási bizonyítás kapcsán engedékenyebbek. Bizonyos döntésekből például az körvonalazódik, hogy a nyomozás során történt bizonyításfelvételre vonatkozó szabályok megsértései csak kisebb fokú szabálysértések, így az adott bizonyíték (hacsak a törvény ezt a hibát ilyennek nem mondja) felhasználható a bíróság előtt is. Más döntések szerint pedig egyes nyomozási cselekmények (pl. akár gyanúsítotti kihallgatás) elmaradása a vád emelését, és annak bírósági elbírálását nem akadályozza, mert a bírósági eljárás alapja a vád, és nem az azt megalapozó nyomozás. ${ }^{81}$

\subsection{A 2017. ÉVI XC. TÖRVÉNY (BE.)}

A hatályos Be. ismét jelentősen új szemléletet kívánt bevezetni a nyomozásban. Ennek lényege, hogy a nyomozást - az első gyanúsítást jelölve meg határpontként - felderítésre és vizsgálatra osztotta. A törvény indokolása két fő okot jelöl meg e szerkezet okául. Az első az ügyészségi és nyomozó hatósági feladatok és kapcsolatrendszer újragondolása, a másik, kevésbé markánsan megfogalmazott ok a felderítés és a vizsgálat bizonyítási „módszereiben” való különbség, amely alkalmat kínál(na) egy egyszerübb, gyorsabb nyomozás lefolytatására a kisebb jelentőségü ügyekben.

79 2006. évi LI. törvény.

${ }^{80}$ Ez egyébként a védők részéről sem volt kívánalom. Sőt, számos esetben megfogalmazódott kvázi kontradiktórius lehetőségek bevezetése már a nyomozási szakaszban is a védelem hatékonyabb gyakorlásának érdekében. Pintér például a védelem jogainak a tanúk nyomozási kihallgatását illető kiszélesítése mellett is érvel. PINTÉR István: „Féloldalas nyomozás, féloldalas tárgyalás” Fundamentum 1997/2. 116-118.

81 Így pl. a BH 2012. 11. 458. számú kúriai döntés kimondja, hogy „A törvényes vád alaki következménye nem nyomozás, vádelökészítés, hanem - azok következménye - a benyújtott vád alapján képezheti vizsgálat tárgyát. Ebből következően a felülvizsgálat nem terjedhet ki - a vádemelési jogosultság (alaki legitimáció) vizsgálata címén - a vád előkészítési, nyomozási szakok vizsgálatára.” A BH 2005. 7. számú döntés szerint pedig „A nyomozás folytatása a kétéves határidő eltelte után eljárási szabályt sért, de az ennek során beszerzett bizonyíték a vádemelés szakaszában és a bírósági eljárásban felhasználható.” A BH 2003. 5. 183., BH 2003. 148., BH 2003. 50., BH 2002. 367 számú döntések pedig azt erősítik, hogy a gyanúsítás elmaradása nem akadálya a (távollétes) vádemelésnek és a vád elbírálásának. 
Az első ok törvényi megjelenítése az, hogy az ügyészség a felderítés során törvényességi felügyeleti jogkört gyakorol, míg a vizsgálat során már irányítási feladatot végez. Utóbbi jellegzetes eszköze a korábbi Be.-ben mindvégig jelen levő, az új törvényben viszont már csak a vizsgálati irányításnál alkalmazható ügyészségi utasítási jog [Be. 26. § (3) bekezdés b) pont]. Mindezek jogalkotói célja az volt, hogy a felderítés során a nyomozó hatóság jóval nagyobb önállóságot kapjon. ${ }^{82}$

Fontos azonban tudnunk, hogy a törvény tervezetének eredeti szövege még merőben másként értelmezte volna a felderítést, mint ahogy azt a végleges szöveg teszi. A Be. egyébként a nyomozás általános feladatát már nem határozza meg úgy, mint az előző törvény tette, csak a két szakaszt definiálja önállóan: „A felderítés során a megalapozott gyanú megállapításához szükséges mértékben fel kell deríteni a bűncselekményt és az elkövető személyét, valamint fel kell kutatni és biztosítani kell a bizonyítási eszközöket." Itt tehát a törvény csak a bizonyítékok felkutatásáról és biztosításáról beszél, nem pedig tényleges bizonyításról, utóbbi szerepet a vizsgálatnak szánja: „A vizsgálat során - szükség esetén bizonyítási eszköz beszerzése és megvizsgálása útján - az ügyészség dönt a gyanúsítottal szemben folyamatban lévő nyomozás befejezésének kérdésében." Ennek jól meg is felelt volna a törvény tervezett szövegében lefektetett rendelkezés, amely szerint a nyomozó hatóság elsősorban adatszerző tevékenységet folytathatott volna a felderítés során, bizonyítási cselekményeket azonban csak meghatározott keretek között, amely azt jelentette, hogy tanúkihallgatásra és szakértő kirendelésére csak kifejezett ügyészi engedélylyel kerülhetett volna sor (az igazságügyi miniszert XXBJFHÁT/7/2016. számú előterjesztése a Kormánynak, 375. §). A végleges szövegében azonban e korlát már nem jelent meg, így a nyomozó hatóság a gyanúsítotti kihallgatáson kívül bármilyen, akár bizonyítási célú eljárási cselekményt elvégezhet teljes önállósággal (ezt a 31. § (2) és (3) bekezdései egyértelművé is teszik), pontosabban a gyanúsítást is elvégezheti, de azzal átlépteti vizsgálati szakaszba a nyomozást. Mindez azonban már a felderítés törvényi definíciójával is ellentétes, hiszen például a felderítés során végzett tanúkihallgatás nem bizonyítási eszköz „felkutatása” vagy „biztosítása”, hanem bizonyítás (azaz a vizsgálatban végezhető „bizonyítási eszköz beszerzése és megvizsgálása"), az ezzel ellentétes értelmezés indokolatlanná tenné a két szakasz törvényben írt fogalmi distinkcióját.

A felderítés és a vizsgálat eredeti különbségtétele egyebekben már több más rendelkezés révén is jelentősen relativizálódott. A Be. legutóbbi, 2021. január hó 1. napjától hatályos novellája ${ }^{83}$ például tovább erősítette az ügyészség felderítési eszköztárát. Bár utasítási jogköre még mindig nincs (ez esetben már szinte értelmetlenné válna a két szakasz elválasztása), de immár a nyomozó hatóság felderítés során hozott határozatait is megváltoztathatja (eddig csak hatályon kívül helyezésre volt lehetőség). A Legfőbb Ügyészség pedig az új Be.-hez kiadott Emlékeztetőjének (LFNIGA//142/2019) legutóbbi szövegezésében már merőben másként értelmezi a

\footnotetext{
${ }^{82}$ Megjegyzem, a Be. 392. §-a a nyomozó hatóságnak a vizsgálati szakaszban is jelentős önállóságot biztosít, azaz beszámolásai alkalmával folyamatosan végezheti az általa tervezett eljárási cselekményeket, nem kell az ügyészség utasításaira vagy jóváhagyásaira „várakoznia”.

83 2021. évi XLIII. törvény 271. § 5. pont.
} 
felderítési felügyeleti jogkört, mint ahogy azt a jogalkalmazók a törvény hatálybalépésekor elképzelték. A kezdeti hozzáállása az volt, hogy a felderítésbe az ügyészség egyáltalán ne szóljon bele, csak ha (mondjuk úgy alaki) törvénysértést észlel, vagy ha panaszt bírál el. Ez a fajta be nem avatkozási doktrína azonban (lényegében mindkét fél részéről) tarthatatlannak bizonyult, különösen a jelentős büntetőügyekben. Az Emlékeztető a törvényességi felügyelet lehetőségét a Be. 163. §-ában írt előírás megtartására is vonatkoztatja, amely nem más, mint az anyagi igazság elve, azaz a valósághủ tényállás felderítésére való törekvés. Az Emlékeztető 26. § 8) pontjának 7. bekezdése ugyanis ekként fogalmaz: „Minden olyan intézkedés, bizonyítási vagy nyomozási cselekmény, vagy annak elmulasztása, amely a valósághủ tényállás megállapítását hátráltatja, törvénysértő, s így a felügyelő ügyész intézkedését kell, hogy kiváltsa. Nem mond ellent ez annak az elvnek, hogy a nyomozó hatóság a felderítést teljes önállósággal végzi, amelyért kizárólagos felelősséget visel."

Mint említettem, egy másik érv is szerepel az osztott nyomozás mellett a törvény indokolásában: „A felderítés szakaszának jellemzője, hogy viszonylag kötetlen formával az adatok - nem elsődlegesen a bizonyíték - gyüjtésére koncentrál. [...] Ezzel szemben a vizsgálat [...] a vádemelés eldöntéséhez szükséges bizonyítási eszközök beszerzésére irányul, ami a „kétszeres bizonyítás” visszaszorítására irányuló jogalkotói törekvést is tükrözi. E koherens szabályozás megteremti a lehetőségét a tömegesen előforduló, egyszerübb megítélésü ügyek hatékonyabb, gyorsabb elintézésének, a bonyolult ügyek - megfelelő ügyészi kontroll melletti - eredményesebb lefolytatásának.” A törvényszövegből ezen elképzelés egyébként kiolvasható, hiszen a felderítés nem ír elő bizonyítást, a vizsgálat esetében pedig szintén csak „szükség esetén” kell bizonyítási eszközt beszerezni és megvizsgálni. Úgy vélem azonban, hogy ez az egyszerűsítési lehetőség sem tudott (és vélhetően nem is fog) gyökeret verni a gyakorlatban, és továbbra is mind az ügyészség, mind a nyomozó hatóság részéről a teljes körű bizonyításra törekvés a jellemző. Utóbbi álláspontnak pedig szintén van törvényi alapja, hiszen a bizonyítás szabályai között a már említett 163. § (2) bekezdés nemcsak elöírja a „valósághü” tényállásra törekvést, de ennek - sőt még a bizonyítékok értékelésére vonatkozó szabálynak [167. § (4) bekezdés] is - címzettjeként már nyomozó hatóságot is megjelöli. E két rendelkezés is ellentmondásos tehát.

\section{5. ÖSSZEGZÉS ÉS KÖVETKEZTETÉSEK}

Igyekeztem láthatóvá tenni, hogy a nyomozás mint büntetőeljárási forma már régtől jelen van a jogrendszerekben, még ha szerepe, szabályozása jelentős eltéréseket is mutat. Áttekintve a történeti előzményeket is, arra a következtetésre juthatunk, hogy az olyan eljárási rendszerekben, amelyek valamennyire is az objektív bizonyítékokra építenek (tehát a döntést nem kizárólagosan istenítéletek eredményeként hozzák meg), ott elengedhetetlenül felmerül annak a szüksége, hogy a vádemelésért felelős (vagy a vádat mellőző rendszerekben, az ítélet megalapozásáért felelős) legalább olyan mértékủ előkészítő tevékenységet végezzen a bírósági elbí- 
rálása előtt, amely ha másra nem, a bizonyítékok beazonosítására szolgál. Ez tulajdonképpen azért is szükségszerü, mert legalábbis az állami bűnüldözés kialakulásától az eljáró hatóságok alaphelyzetben el vannak választva a büncselekménynek minősülő eseményektől, annak nem részei. Épp ezért a bírósági eljárás „vaktában”, bármiféle adat hiányában való kezdeményezése nem lehetséges, tehát valamilyen előzetes vizsgálódással meg kell azt alapozni.

Azt is láthattuk, hogy míg az inkvizitórius rendszerek a nyomozásra építettek, addig a kontinentális vegyes rendszerekben kezdetben a nyomozás szükségszerüen megmaradt, de annak csak előkészítő szerepet szántak a perszakaszhoz képest. Később azonban a nyomozás megerősödött, és a tárgyalási fázissal egyenértékủ eljárási szakasszá vált. Az angolszász jogrendekben szintén kialakult a nyomozási szakasz, de annak szerepe, szabályozottsága a mai napig - bár erősödés itt is látható - kevésbé jelentős a bírósági eljáráshoz viszonyítva.

A kontinentális és az angolszász rendszerekben rejlő különbség legföbb oka nézetem szerint a nyomozás során történő igazságfeltárás módjában keresendő. Ezen elvi alapnak csak következményei az olyan jellegzetességek, minthogy az angol és amerikai jogrendben kevésbé és máshogy szabályozott a nyomozás, vagy hogy egyáltalán a büntetőeljárás részének tekintik-e. Az igazságkeresés közti különbség röviden akként foglalható össze, hogy míg az angol-amerikai jogrendszerek megelégednek azzal, nyomozás során adatgyűjtés, a (leendő, tárgyaláson felmutatandó) bizonyítékok beazonosítás folyjék, addig a kontinentális, de legalábbis a magyar nyomozás a „teljesség” elvét követi, azaz a nyomozás során alapos bizonyítás folyik a tényállás leginkább teljes körü felderítése és egyben bizonyítása érdekében. ${ }^{84}$

Utóbbi kapcsán pedig úgy látom, hogy a magyar vegyes rendszer már az első perctől fogva nem tudott elszakadni a nyomozás ezen „maximalista” felfogásától (valójában az inkvizitórius hagyatékoktól), annak ellenére, hogy ciklikusan, szinte valamennyi kódexben történt jogalkotói kísérlet valamilyen egyszerűsítő, a „túlbizonyítás" ellen ható eljárási forma bevezetésére. Az is jól látható, hogy a joggyakorlat volt az, amely - akár jogalkotói, akár jogtudományi elképzelések ellenére - mindig visszatért ahhoz, hogy a tényállást már a nyomozás során is teljeskörűen, és megfelelő - a későbbi bírósági döntés alapjául is szolgáló - bizonyítékokkal körülbástyázva kell megállapítani.

Ez a koncepció azonban nem feltétlenül a szocialista jogalkotás és jogalkalmazás terméke. Már az I. Bp. esetén is azt láthattuk, hogy hiába pusztán a vádló tájékoztatása érdekében történő adatgyüjtés a nyomozás törvényi célja, és hiába nevezték azt előkészítő szakasznak, a joggyakorlat - ahogyan erről a korszak jogalkalmazói beszámolnak - mégiscsak a teljes körủ bizonyítás irányába mozdult el.

${ }^{84}$ Már több ízben szóltam a teljeskörűség elvéről. E ponton mindenképpen szükséges tisztázni, hogy ez a felderítettség és a bizonyítottság tekintetében nem azonos, a nyomozás esetében utóbbi a problémás kérdés. Lakatos találóan mutat rá a különbségre, amikor azt mondja, hogy a felderítettség saját magunk meggyőzése a valós történtekröl, míg a bizonyítottság a mások meggyőzését jelenti. Emiatt lehet egy ügy teljeskörüen felderített (a nyomozó a beszerzett adatok alapján mindent megtudott), de nem biztos, hogy teljeskörüen bizonyított is lesz (a tanúk végül nem azt mondták el a kihallgatáson, mentességi jogukkal éltek stb.). Sokszor ez a helyzet okoz nézeteltérést a nyomozó hatóság és az ügyészség között. Ld. BALLÁNÉ-Kunos-LaKatos (3. lj.) 100. 
A II. Bp.-től kezdve pedig a kódexek - és ennek megfelelően a jogtudomány és a jogalkalmazás is - már egyértelmủen úgy foglaltak állást, hogy a nyomozás a tárgyalással egyenértékű főszakasz, ahol teljes körü tényfeltárásnak és bizonyításnak is kell folynia. Ezt csak részben enyhítették az I. és II. Be. egyszerűsített, illetve vétségi nyomozásra vonatkozó szabályai. Utóbbiak esetén azt kell ugyanis látni, hogy az egyszerűsítés formai jellegű volt (pl. jelentés jegyzőkönyv helyett), de tartalmi könnyítésről szó sem lehetett, azaz a teljes körű tényfeltárás, és ennek bizonyító erejü alátámasztása ekkor sem maradhatott el.

A III. Be. bár megcélozta a nyomozás előkészítő szerepbe való visszaszorítását, és ez a nyomozás feladatának meghatározásánál végig megmaradt a törvényszövegben, azonban az anyagi igazság követelménye végül bekerült a törvényben, míg a teljeskörüséget, és annak adminisztratív terheit enyhítő rendelkezések (pl. jelentés készítése vallomásokról) viszont kikerültek. A joggyakorlat pedig ez esetben sem tudott megengedővé válni, és a nyomozás alaposságának és a teljes körủ bizonyításnak az eszméje sem az ügyészi, sem a nyomozó hatósági gyakorlatból nem tudott kikopni. Utóbbi érthető is, hiszen mind a pozitív törvényi elöírások, mind a folyamatosan magas váderedményesség „ördögi köre” nem engedi, hogy a vádhatóság egyik percről a másikra átálljon, vagy legalábbis egyes ügyek esetében megelégedjen egy alacsonyabb szintủ bizonyossággal a vádat alátámasztó anyagot illetően.

Végül a hatályos Be. a felderítés és a vizsgálat elválasztásával szintén megcélozta egy egyszerübb nyomozási forma lehetőségét. Ez a koncepció azonban elsősorban csak a törvény indokolásában jelent meg, és bár a felderítés és a vizsgálat törvényi fogalmaiból is levezethető, azonban a végleges törvényszöveg elvetette a felderítése adatgyűjtő jellegét, és a bizonyítás kivételességét, így a joggyakorlatban sem indult meg tudomásom szerint ilyen irányú változás. Ez tehát azt jelenti, hogy a kisebb, egyszerübb ügyekben sem jellemző, hogy ne a teljes körü bizonyítás lenne a mérvadó (mint a III. Be.-nél jeleztem, ezt maga a törvény sem engedi meg az anyagi igazságra törekvés deklarálása révén), még azon esetekben sem, ahol az ügyészség végül nem a vádemelés, hanem annak valamelyik alternatívája mellett dönt, holott a Legfőbb Ügyészség folyamatosan felhívja a figyelmet a túlbizonyítás elkerülésére is. Mindemellett, ahogy azt szintén részleteztem, mára már a felderítés és a vizsgálat határai is kezdenek elmosódni. Tény, hogy az új Be. nagy számban teszi lehetővé a gyorsító, egyszerűsítő lehetőségeket, azonban ezek nem a nyomozást, hanem a bírósági eljárást vagy legalábbis az ottani bizonyítást egyszerūsítik. ${ }^{85}$

$\mathrm{Az}$ általam korábban feltett három kérdés kapcsán végül úgy látom, hogy az eljárási szakaszok viszonyát illetően a magyar jogban továbbra is a nyomozás tárgyalással egyenértékű szakaszként való felfogása a jellemző. A nyomozás „mélységét”

85 Így pl. a bíróság elé állítás hiába alkalmaz rövid határidőket és gyors tárgyalást, azonban semmi nem írja elő, hogy a nyomozást is egyszerűsíteni lehetne. Mi több, a szoros határidők a gyanúsítástól indulnak, így azt akár egy hosszabb, bizonyítékbeszerzést illetően alapos felderítés is megelőzheti. Ugyanez igaz a büntetővégzés meghozatalára irányuló eljárásra: hiába marad el a tárgyalás, azt akár igen alapos nyomozás is megelőzheti. Sőt, azt kell összességében mondanunk, hogy a tárgyalást elkerülő valamennyi forma esetén (előkészítő ülés, egyezség) épp a széleskörűen beszerzett nyomozási bizonyítékok jelentik a bírói döntés alapját. 
illetően a korábban kifejtettek szerint tulajdonképpen az első kódexünktől kezdve a hatályos jogig a teljes körü felderítettségre és bizonyítottságra törekvés a meghatározó a nyomozás során is. A felosztást illetően szinte mindenhol láthatunk ilyen törekvést, ám ez - az I. Bp. óta - a legmarkánsabban a hatályos törvényben jelenik meg. Az viszont, hogy ez utóbbi megoldás és a másik két kérdésre adott válasz „jó-e”, illetve beválik-e a jogalkalmazásban, már (még) jelen tanulmány keretei között nem válaszolható meg. Mindezeken túl adós maradtam az osztott nyomozás bevezetése okának feltárásával. A pontos okot azonban megtalálni nem tudtam, mert egyrészt arra sem a törvényszöveg, sem annak indokolása nem ad választ, másrészt a felosztás nem feleltethető meg az egyéb vagy korábbi teóriáknak. Tény, hogy a jogtudományban és a kriminalisztikában megjelenik a felderítésre és bizonyításra/ vizsgálatra osztás (utóbbi két kifejezés tartalma azonos), azonban ennek a jelenlegi törvényszöveg nem feleltethető meg, legfeljebb a két eljárási szakasz definiálásakor láthatunk néminemủ egyezést. A tudományban alkalmazott felosztás lényege ugyanis az adatgyűjtő-jellegű felderítés és a bizonyító jellegű vizsgálat kettősségében határozható meg, ezt azonban sem a törvényi rendelkezések, sem a jogalkalmazói gyakorlat nem jeleníti meg. Így a felosztás jelenleg kizárólag az ügyészség és a nyomozó hatóság kapcsolatának és feladatainak elhatárolásában (lényegében az utasítási jog kérdésében) realizálódik. 